\title{
The glacial history of the southern Svartenhuk Halvø, West Greenland
}

\author{
Timothy P. Lane ${ }^{1}$ - David H. Roberts ${ }^{2}$ Colm Ó Cofaigh ${ }^{2} \cdot$ Andreas Vieli $^{3}$. \\ Steven G. Moreton ${ }^{4}$
}

Received: 16 September 2015/ Accepted: 21 October 2015

(C) Springer-Verlag Berlin Heidelberg 2015

\begin{abstract}
This paper presents a new, detailed geomorphological and sedimentological appraisal of the southern Svartenhuk Halvø, a remote area of West Greenland that has only been subjected to limited geomorphological and sedimentological research. Despite this, it is of importance as several studies have suggested it remained an ice-free enclave during the Last Glacial Maximum. This previous work, based on biostratigraphic and chronological evidence, has provided evidence for the 'Svartenhuk Marine Event', a period of ice free conditions and marine deposition into a higher than present relative sea-level during the previous interglacial (MIS 5a-e). This has been correlated to other interglacial deposits in West Greenland. New geomorphological and sedimentological investigations from this study present compelling arguments for the glaciation of southern Svartenhuk Halvø by valley glaciers and mountain ice caps, questioning the status of this peninsula as an ice-free enclave. Ice directional indicators and clast lithological results suggest ice covering Svartenhuk Halvø was sourced from the higher altitude interior of the peninsula and expanded to the present coastline. In a number of valleys, sedimentological evidence points to at least two glacial advances with subglacial till production through the reworking of glaciomarine sediments, and ice contact and glacier-fed delta deposition during phases of ice
\end{abstract}

Timothy P. Lane

t.p.lane@ljmu.ac.uk

1 School of Natural Sciences and Psychology, Liverpool John Moores University, Liverpool L3 3AF, UK

2 Department of Geography, Durham University, South Road, Durham, UK

3 Department of Geography, University of Zurich - Irchel, Winterthurerstr. 190, 8057 Zurich, Switzerland

4 NERC Radiocarbon Laboratory, Scottish Enterprise Technology Park, East Kilbride G75 0QF, UK retreat. The geomorphological and sedimentological context of the sediments (Gilbert type deltas), coupled with evidence for eskers and kettled/pitted delta surfaces, suggests these features formed under glacial and not interglacial conditions. This is supported by new radiocarbon dates which suggest outlet glacier advance and retreat across the area towards the end of MIS 3 and possibly into the Early Holocene. Svartenhuk Halvø was not overrun by the main Greenland Ice Sheet during the last glacial cycle, but the development of an independent ice cap and local outlet glaciers across this region may have been instrumental in determining the dynamic evolution of the Uummannaq ice stream onset zone during the last glacial cycle.

Keywords Greenland · Glacial geomorphology · Glacial sedimentology · MIS 3-5 environments

\section{Introduction}

Ice sheets are well known to exert major impacts upon landscape evolution at local, regional and continental scales and have done so throughout the Quaternary [84, 90]. The ice-free periphery of the Greenland ice sheet (GrIS) is a unique region in which to investigate landscape evolution, as its form is a result of repeated ice sheet erosion during Pleistocene cold periods and potential interglacial sediment deposition during warm periods. The present ice-free landscape of Greenland is dominated by landscapes resulting from ice sheet activity (e.g. areal scour and selective linear erosion) and those formed through the action of independent valley and mountain glacier systems [54, 84]. During full glacial conditions, the majority of land surrounding Greenland was inundated and covered by thick, ice stream and interstream ice as it moved offshore [35]. Indeed, at the Last Glacial 
Maximum (LGM), the GrIS in West Greenland was drained by a series of large, cross-shelf ice streams which terminated at, or close to, the shelf-edge and produced large trough mouth fans $[55,68,69,78,80]$. The location and longevity of these systems are likely to have had an important impact upon landscape evolution and modification [78, 79, 85].

Despite evidence for extensive glacial erosion of the icefree coastal hinterland of Greenland, a number of lowland regions were thought to have remained ice-free throughout glacial cycles, acting as refugia for plants during glacial periods [37] and displaying "little or no evidence of glacial erosion" [84]. Areas classified as ice-free during glacials appear highly localised in their distribution, and it has been suggested that a local combination of factors are required to generate and then preserve such landscapes [84]. Restricted GrIS coverage [22] and higher than present sea levels would have made these regions potential sinks for sediments during MIS5e or earlier interglacial periods $[33,51]$. In such areas the absence of erosion by the GrIS has allowed for the preservation of sediments deposited prior to the last glacial cycle. These areas would have potentially developed due to the intense focusing of ice flow which occurs in ice streams, starving peripheral, interstream areas of warm-based ice. This would leave them ice-free, or more likely stranded as fields of cold-based ice [53, 54]. It is also possible that the existence of persistent, cold-based ice helped to preserve the sedimentary deposits throughout such regions. One such topographic and glaciological setting, identified by Sugden [84], is the Svartenhuk Halvø. This landmass is thought to have been minimally effected by the nearby Uummannaq Ice Stream (UIS) during Late Quaternary glacial periods [55, 80], instead being occupied by local mountain and plateau glaciers of limited extent. This is thought to have allowed the preservation of thick glacial and marine deposits, an unusual situation in West Greenland, which is more typically characterised by glacially scoured surfaces and an absence of glacial sediments. The deposits on Svartenhuk Halvø are thought to have been deposited during the last interglacial, during a period termed the "Svartenhuk Marine Event" (SME) (see below).

This paper aims to: (1) reconstruct the pre-LGM and LGM glacial history of the Svartenhuk Halvø landscape; (2) investigate the morphology and sedimentology of landforms throughout the southern coast of Svartenhuk Halv $\varnothing$; and (3) improve the chronological framework for the landforms and deposits in this region, in order to reconstruct the glacial history of the peninsula.

\section{Svartenhuk Halvø}

The Uummannaq region covers an area of $\sim 25,000 \mathrm{~km}^{2}$ $\left(70.33^{\circ} \mathrm{N}\right.$ to $72.00^{\circ} \mathrm{N}, 50.00^{\circ} \mathrm{W}$ to $\left.55.00^{\circ} \mathrm{W}\right)($ Fig. 1$)$ and is one of the most mountainous areas of West Greenland, with summits reaching $>2000 \mathrm{~m}$ a.s.l. It is bounded to the north and south by large peninsulas which form large topographic barriers, confining the flux of ice and water from the Uummannaq region to the narrow passages north and south of Ubekendt Ejland. The Svartenhuk Halvø ( $\sim 4000 \mathrm{~km}^{2}$ ) borders the northern edge of the Uummannaq region. The west of the peninsula is formed of transitional basalts and theoliites, the northern central region is formed of hyaloclastite, and the east is picrite and olivine basalt (Fig. 2a) [45, 46]. The areas are characterised by relatively low altitudes with summit heights in the west of the peninsula being below $1000 \mathrm{~m}$ a.s.l. and those in the east $1100-1200 \mathrm{~m}$ a.s.l. Several small $\left(<5 \mathrm{~km}^{2}\right)$ mountain valley glaciers exist in the central and western portions of the peninsula (Fig. 2b). The southern coast is characterised by four large valley systems which drain the interior of the peninsula. At the LGM, areas to the east and south of Svartenhuk Halvø were occupied by the UIS, with LGM ice surface elevation constrained to $\sim 1400 \mathrm{~m}$ a.s.1. [55, 69, 80]. Trunk flow from the northern UIS would have been deflected south by Ubekendt Ejland into Igdlorssuit Sund, coalescing with southern outlet glaciers (Fig. 1) [25, 55, 69, 80].

\section{Geomorphology and sedimentology}

The Svartenhuk Halvø region has been subject to a long history of sedimentological and palaeoecological investigation (Table 1) [13, 32, 56, 77, 83], but despite this, the Pleistocene history of the peninsula is not fully understood. Early research reported the area to be dominated by a fluvial system with a widespread, thin, locally sourced, sediment cover of unknown genesis (Fig. 2b) [56]. This led to the suggestion that the peninsula either remained icefree, or fostered cold-based ice caps during the Last Glacial Maximum. A thin cover of morainic material, containing occasional erratic boulders, is recorded from the interior of the peninsula [56], and a number of valley glaciers in the interior of the peninsula feature moraines, indicating periods of more spatially extensive ice cover [56]. Sugden [84] classified southern and western Svartenhuk Halvø as displaying little or no glacial erosion, with the north and east classified as landscapes of cirque glaciers and plateau remnants. Recent mapping has reclassified a larger proportion of the peninsula as areas of mountain valley and cirque glaciers [54]. Sedimentological studies in Svartenhuk Halvø reported the presence of deltaic deposits with in situ marine molluscs (thought to be glacioisostatically uplifted), widespread shell-bearing littoral gravel and sublittoral muds, and a single exposure of diamicton [13]. Most of the sites reported were thought to represent palaeospits, cuspate forelands, alluvial cones and deltas, which extend up to $35 \mathrm{~m}$ a.s.l. [13]. Biostratigraphic 


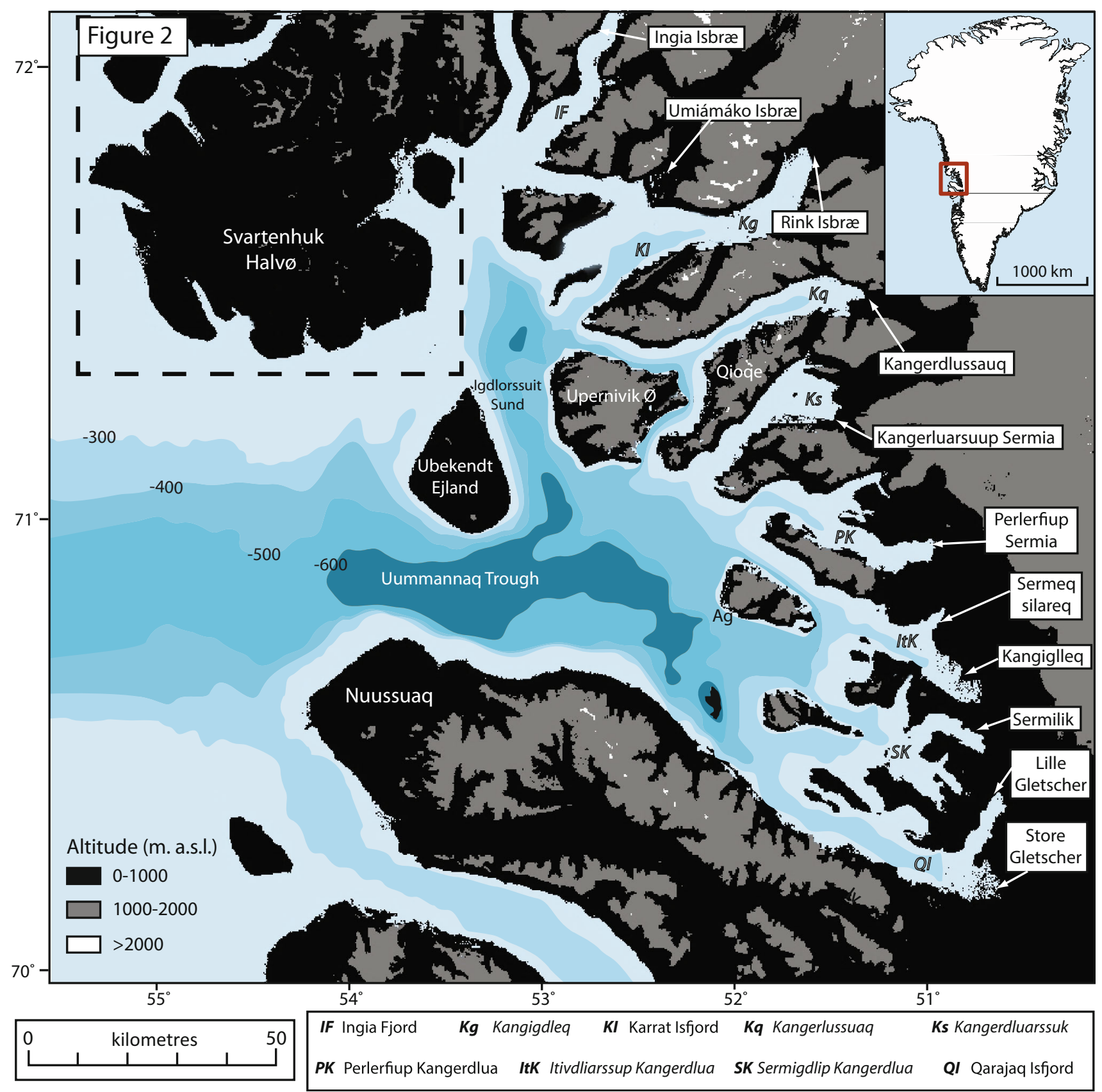

Fig. 1 Topographic overview map of Uummannaq region. Altitudes are taken from ASTER imagery and bathymetry from GEBCO

investigation of the sediments demonstrated some discrepancy between the mollusc data and the microfossil data [13]. Biostratigraphic indicators from 12 sites provided marine macrofauna reconstructions suggesting conditions analogous to the Holocene in North Greenland; ostracod assemblages representing a quiet shallow marine environment analogous to present-day Disko Bugt; and foraminiferal assemblages suggesting subarctic and glacier distal conditions [13, 51, 56] (Table 2).

\section{Chronology}

Previous dating campaigns have focused on providing dating control for the Svartenhuk Marine Event and the raised marine deposits detailed above. The majority of radiocarbon dates from shells across Svartenhuk Halvø are reported as probable infinite ages $>30,000-40,000{ }^{14} \mathrm{C}$ years $\mathrm{BP}$, with one finite age of $37,970 \pm 2470 / 1890{ }^{14} \mathrm{C}$ years BP [13, 51]. Amino acid determinations from marine shells taken from 
Fig. 2 a Enlargement of the Svartenhuk Peninsula, with investigated sites and valleys discussed in the text labelled. In addition, surficial deposits of glaciofluvial/fluvial and marine sediment are shown, from Henderson and Pulvertaft [45, 46]. b Geology map of the Svartenhuk peninsula showing bedrock geology and surficial deposits. Reproduced from [47]. The calibrated radiocarbon age to the north-east of the region is from Bennike [12] and represents the only Holocene shell age in the region
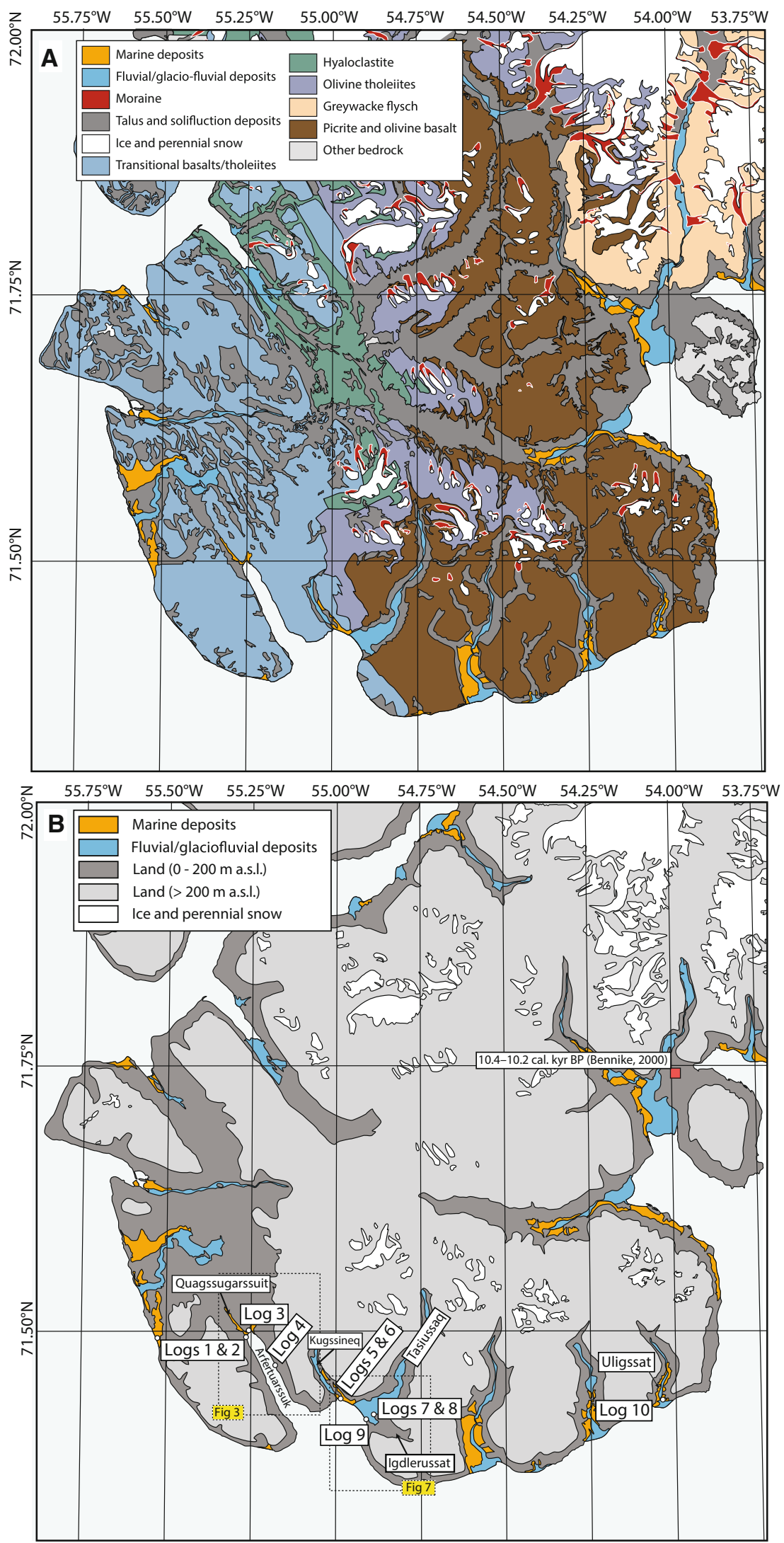
Table 1 List of locations logged in this study, their log number and a reference if they have been studied by previous authors

\begin{tabular}{lllll}
\hline Log \# & Site name & Lat. $\left({ }^{\circ} \mathrm{N}\right)$ & Long. $\left({ }^{\circ} \mathrm{W}\right)$ & References (Site \# in their text) \\
\hline 1 & Arfertuarssuk fjord head 1 & 71.495 & 55.256 & Bennike et al. [13] (6); Kelly et al. [51] (15) \\
2 & Arfertuarssuk fjord head 1 & 71.495 & 55.256 & Bennike et al. [13] (6); Kelly et al. [51] (15) \\
3 & Arfertuarssuk fjord head 2 & 71.500 & 55.217 & Bennike et al. [13] (8) \\
4 & Arfertuarssuk fjord side 1 & 71.468 & 55.168 & Bennike et al. [13] (9) \\
5 & Kugssineq Coast & 71.450 & 55.001 & Bennike et al. [13] (10); Kelly et al. [51] (16); Laursen [56] \\
6 & Kugssineq Coast & 71.450 & 55.001 & Bennike et al. [13] (10); [51] (16); [56] \\
7 & Igdlerussat & 71.422 & 54.882 & New location \\
8 & Igdlerussat & 71.422 & 54.882 & New location \\
9 & Tasiussaq & 71.415 & 54.905 & Bennike et al. [13] (12) \\
10 & Uligssat qôruat & 71.436 & 54.031 & New location \\
\hline
\end{tabular}

Table 2 Table of present chronological control from the southern and western Svartenhuk Peninsula

\begin{tabular}{llllll}
\hline Log \# & Elevation (m a.s.1.) & Age $\left({ }^{14} \mathrm{C}\right.$ years BP) & $\delta^{13} \mathrm{C} \%$ & Lab number & References \\
\hline 1 & - & $>40,000$ & - & - & Kelly [51] \\
3 & 22 & $>40,000$ & 0.1 & RCD-22 & Bennike et al. [13] \\
$5 / 6$ & 7 & $>36,600$ & -0.3 & K-5511 & Bennike et al. [13] \\
11 & $0-2$ & $37,570 \pm 2570 / 1890$ & - & Ua-1790 & Bennike et al. [13] \\
12 & $8-10$ & $>32,530$ & 1.4 & K-5514 & Bennike et al. [13] \\
14 & 14 & $>30,400$ & 0.9 & K-5513 & Bennike et al. [13] \\
16 & 35 & $>34,710$ & K-5512 & Bennike et al. [13] \\
\hline All ${ }^{14} \mathrm{C}$ except one returned infinite ages. Samples are from marine shells; T. borealis, M. truncate, H. \\
arctica, P. arctica and A. borealis
\end{tabular}

sites throughout Svartenhuk Halvø returned aIle/Ile ratios of $F=0.182$ and $T=0.0236$ (12 samples) [51], and $F=0.173$ and $T=0.032$ (8 samples) [13], suggesting an age of $>55 \mathrm{kyr}$ [51]. Finally, two U/Th dates from marine shells returned ages of $>89$ and $115 \mathrm{kyr}$ (no errors given) (quoted in [34]; as from [51]. On the basis of this chronology, sediments and macrofossil assemblages found across the Svartenhuk Halvø coastal zone were proposed to represent sediments deposited during a period of elevated sea level ( $\sim 35 \mathrm{~m}$ a.s.l.) in MIS 5e-a, $\sim 115 \mathrm{kyr}$, named the Svartenhuk Marine Event [13, 33, 51]. The age and preservation of SME sediments support the hypothesis that ice from the GrIS had minimal impact upon Svartenhuk Halvø during the LGM. Despite these findings, our understanding of the glacial and interglacial history of Svartenhuk Halvø remains fragmentary, with little appreciation of the genesis of the sediment/landform assemblages along the coastline.

\section{Methods}

\section{Geomorphological mapping}

Regional geomorphological mapping was carried out using 1:50,000 topographic maps, geological maps [45, 46],
1:150,000 aerial photographs (Kort and Matrikelstyrelsen) and ASTER GDEMs, focusing upon the southern coast of Svartenhuk Halvø. These were ground-truthed in the field. Glacial, glaciofluvial and fluvial landforms were identified and mapped, and a Garmin GPS 60 was used to record their location.

\section{Sedimentology}

Sediment exposures were logged and sketched, noting any lateral sediment variability and macroscale sediment structure. Sediment description adopted a lithofacies approach [27, 28]. Clast form analysis was performed upon clasts from gravel and diamicton units ( $n=50$ per unit), measuring clast morphology and roundness on the Powers' roundness scale [8]. Clast form was presented using ternary diagrams $[6,8,63,81]$. Clast $\mathrm{C} 40$ index (percentage of clasts with a c:a ratio of $\leq 0.4$ ) was used to distinguish blocky from elongate clasts $[2,6,8]$. RA indexes were calculated by adding the percentages of very angular and angular clasts. Clast fabric data were collected from units of diamicton [28]. The orientation and dip of fifty elongate clasts within a $1 \mathrm{~m}^{2}$ exposure were measured for each sample. Eigenvalues were calculated for samples, and results were plotted as stereonets and rose diagrams using 
the RockWare RockWorks software package. Sediment samples were taken from each sedimentary unit for laboratory particle size measurement. Laboratory-based particle size was determined for the $<2 \mathrm{~mm}$ fraction using laser diffraction, widely regarded as providing the greatest reproducibility $[40,82]$.

\section{Radiocarbon dating}

Plant fragments and shells were collected for radiocarbon dating from sediments at all sites, where found. Terrestrial plant macrofossils and shells were recovered from exposed sections using a clean trowel, placed in plastic sample bags and refrigerated before being sent to the NERC Radiocarbon Laboratory, East Kilbride, for analysis. In order to ensure that dated shells were in situ only paired, articulated bivalves were sampled. Plant macrofossils were digested in $2 \mathrm{M} \mathrm{HCl}\left(80^{\circ} \mathrm{C}, 8\right.$ hours), washed free from mineral acid with deionised water then digested in $1 \mathrm{M} \mathrm{KOH}\left(80^{\circ} \mathrm{C}, 2\right.$ hours). The digestion was repeated using deionised water until no further humics were extracted. The residue was rinsed free of alkali, digested in $2 \mathrm{M} \mathrm{HCl}\left(80{ }^{\circ} \mathrm{C}, 2\right.$ hours) then rinsed free of acid, dried and homogenised. The total carbon in a known weight of the pre-treated sample was recovered as $\mathrm{CO}_{2}$ by heating with $\mathrm{CuO}$ in a sealed quartz tube. Shell, samples were cleaned in an ultrasonic bath in deionised $\mathrm{H}_{2} \mathrm{O}$ for two 2 min.utes and then rinsed in deionised $\mathrm{H}_{2} \mathrm{O}$. Once cleaned the outer $20 \%$ by weight of shell was removed by controlled hydrolysis with dilute $\mathrm{HCl}$. The samples were then rinsed in deionised water, dried and homogenised. A known weight of the pre-treated sample was hydrolysed to $\mathrm{CO}-$ using $85 \%$ orthophosphoric acid at room temperature.

The $\mathrm{CO}_{2}$ from all samples was converted to graphite by $\mathrm{Fe} / \mathrm{Zn}$ reduction. Results in this study have been corrected to $\delta^{13} \mathrm{C}_{\mathrm{VPDB}}-25 \%$ using $\delta^{13} \mathrm{C}$ values from aliquots of sample $\mathrm{CO}_{2}$ measured on a dual inlet stable isotope mass spectrometer (Thermo Scientific Delta V Plus) and are representative of $\delta^{13} \mathrm{C}$ in the original, pre-treated sample material. ${ }^{14} \mathrm{C}$ ages were then calibrated to calendar years using OxCal, with the IntCal13 and Marine13 calibration curves [75].

Whilst samples SUERC-43159, SUERC-43161, SUERC-45900, and SUERC-45905 produced finite radiocarbon ages (Table 4), it should be noted that the results were close to background measurements. For the process standards, bituminous coal and Iceland spar calcite were used which produce consistent low-background results but they do not share the same burial history and may not respond to pre-treatment in the same way as the sample materials. It is, therefore, possible that the age of the older samples ( $>40000{ }^{14} \mathrm{C}$ yrs $\left.\mathrm{BP}\right)$ and the backgrounds could be indistinguishable.

\section{Results}

Geomorphological and sedimentological investigations were undertaken in: Arfertuarssuk; Kugssineq and Tasiussaq; and Uligssat (see Fig. 2; Table 1). Logs were taken from each of the valleys, and the sedimentary sequences recorded have been subdivided into five lithofacies associations (see Table 3). Geomorphological results are presented for each of these three areas, and sedimentological results and interpretations are presented by lithofacies association.

\section{Geomorphology}

\section{Arfertuarssuk and Quagssugarssuit (Logs 1-4)}

Arfertuarssuk is a sheltered, north-west to south-east trending, steep-sided fjord in western Svartenhuk Halvø (Figs. 2, 3) bounded by higher altitude terrain $(>600 \mathrm{~m}$ a.s.l.) to the east and west. The fjord head region and the hinterland to the north rise gently, reaching up to $300 \mathrm{~m}$ a.s.l. in altitude. A series of discontinuous erosional benches are incised into the fjord walls up to a height of
Table 3 Table of lithofacies associations, lithofacies, a short description of each lithofacies and the facies/units from each logged section correlated to each lithofacies association

\begin{tabular}{ll}
\hline Lithofacies & Sediment type \\
\hline LFA1 & Periglacially reworked bedrock \\
LFA2 & Lower matrix-supported diamicton \\
LFA3 & \\
LFA3a & Ice-marginal glacio/fluviodeltaic bottomsets \\
LFA3b & Ice-marginal glacio/fluviodeltaic foresets \\
LFA3c & Ice-marginal glacio/fluviodeltaic topsets \\
LFA4 & Slope deposits \\
LFA5 & \\
LFA5a & Upper matrix-supported diamicton \\
LFA5b & Esker gravel \\
\hline
\end{tabular}


Fig. 3 Geomorphological map of the Arfertuarssuk Fjord and Quagssugaarsuit valley region, showing site numbers referred to in the text

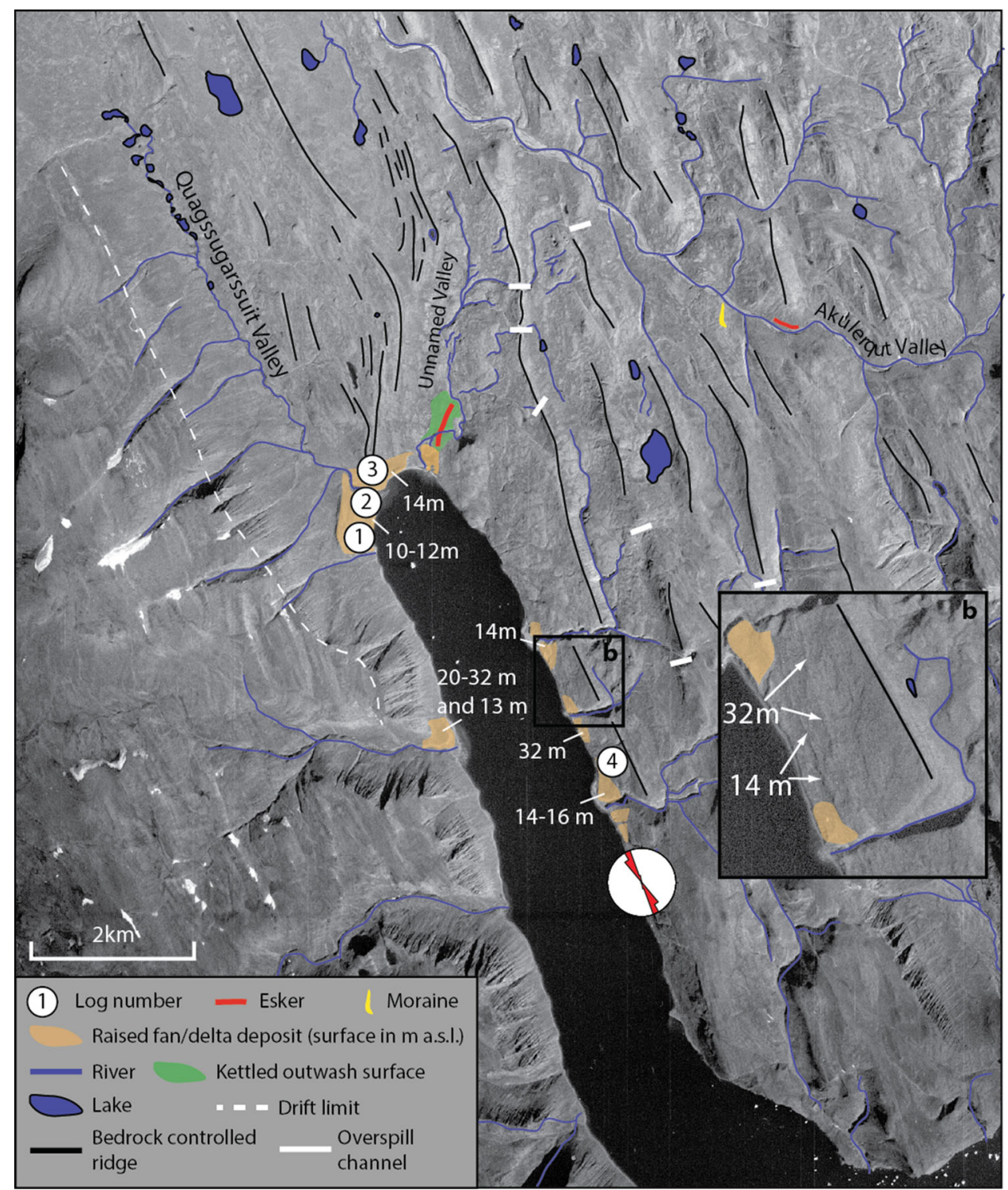

$68 \mathrm{~m}$ a.s.l. These vary in their size and preservation with individual sections reaching up to $500 \mathrm{~m}$ in length and tread depths up to $11 \mathrm{~m}$. In places their surfaces displayed a gravel cap $(>30 \mathrm{~cm})$, formed of coarse gravels held in a sandy matrix. The most prominent bench is at $32 \mathrm{~m}$ a.s.l. and backed by a distinct, frost shattered, fossil cliff line. To the south-east it grades into a flat-topped alluvial fan $(32 \mathrm{~m}$ a.s.l.), at the base of a contemporary fluvial channel (Fig. 4a).

A number of alluvial fans (cf. [18]) are found throughout Arfertuarssuk, formed on terrain to the east, west and north of the fjord. Their surfaces are smooth, displaying gentle apex to toe slopes. Although raised above present sea level (12-32 m a.s.1.), all fans are found at the bases of palaeofluvial channels which would have fed them in the past (Fig. 3). These are interpreted as coastal alluvial fans which formed through sediment aggradation to sea level, subsequently raised by glacioisostatic rebound. The largest of these fans in Arfertuarssuk is on the western side of the fjord, emanating from a deeply incised fluvial channel sourced from high-altitude terrain to the west (Figs. 3, 4b). The fan extends $\sim 500 \mathrm{~m}$ up-valley, and its surface is graded to $\sim 32-20 \mathrm{~m}$ a.s.l. (apex to toe). The fan surface is composed of angular to subrounded local basaltic material held within a silty matrix and has experienced extensive frost heaving.

A number of features with flat-topped upper surfaces graded to 12-16 $\mathrm{m}$ a.s.l. were found at the fjord head (Logs $1-3)$ and in the mid-fjord ( $\log 4)$ of Arfertuarssuk, with no clear source channel/stream. Based upon their geomorphology and sedimentology (see "Sediment descriptions" section), these are interpreted as raised deltas. At the head 

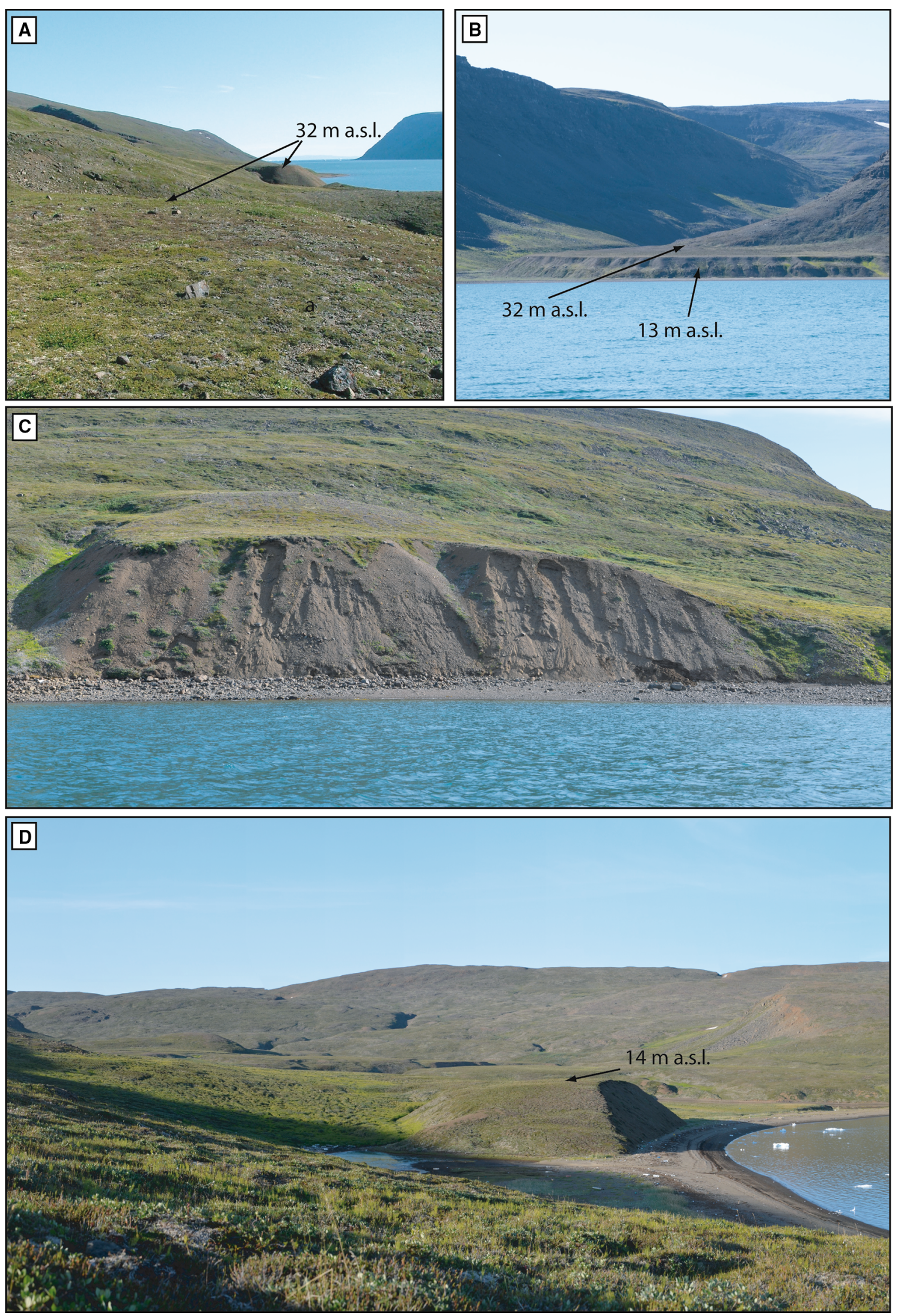
4Fig. 4 Photographs from Arfertuarssuk Fjord: a view south from the $32 \mathrm{~m}$ a.s.1. ridge north of $\log 4$ (see Fig. 6, 6) with clear alluvial fan graded to the same height; $\mathbf{b}$ view south-west from $\log 4$ to an extensive alluvial fan on the west side of the fjord. A clear dipping fan surface can be seen, with an incised step at $13 \mathrm{~m}$ a.s.1.; c view eastwards, looking directly at the location of Log 4-bedding can be seen dipping towards the bottom right; $\mathbf{d}$ view from the surface of the sediment deposit from which Logs 1 and 2 were recorded, looking north-east to the location of $\log 3$. Log 3 was recorded from the $14 \mathrm{~m}$ a.s.l. high mound in the centre of the photo. The valley in the background beyond this is the location in which extensive sediment and an esker were found (see text)

of the valley, a delta appears to infill the southern Quagssugaarsuit valley down to the present coastline. Log 4 is taken from a delta on the eastern side of Arfertuarssuk, mid-way up the fjord (Fig. 3). The feature has a flat top with a gentle south-west dip, graded to $16-14 \mathrm{~m}$ a.s.l. An exposure of heavily striated in situ bedrock (mean direction $160^{\circ}-340^{\circ}$ ) was found at the base of the delta section (see Fig. 3). The narrow, low-lying "Unnamed Valley" to the north-east of Logs 1-3 (Fig. 3) contains a thick sediment infill which continues inland from the coast for $\sim 800 \mathrm{~m}$. It has a smooth surface which dips downstream towards Arfertuarssuk, at a height of 32-16 m a.s.l. The surface has been heavily dissected by contemporary fluvial channels and grades directly into the upper surfaces of deltas at Logs 1 and 2. Although the surface was generally smooth, a series of circular depressions, up to $4 \mathrm{~m}$ in depth and $10 \mathrm{~m}$ in diameter, were found formed across its surface, with no obvious pattern of distribution. Based upon the morphology of this area, it is interpreted as a region of kettled outwash, with an extensive outwash/upper delta surface cratered by circular kettle holes $[5,65]$, resulting from the melt out of buried glacier ice $[41,73,76]$, or through the melt of icebergs deposited on the outwash surface through a flood event [64]. An 80-m long, 1-m-high ridge formed of coarse, unsorted sand and gravel, with locally sourced basaltic pebbles and cobbles was found grading into the flat-topped surface of the delta from the north. Based upon the form, valley position and internal sedimentology of the ridge, it is interpreted as a small esker, formed of glaciofluvial sand and gravel [5, 89].

The terrain north of Arfertuarssuk is rolling and hilly, and is dominated by the low-lying Quagssugaarsuit valley (Figs. 3, 4d, 5a, b). The area is characterised by a series of NNW-SSE trending bedrock-controlled ridges, elevated up to $100 \mathrm{~m}$ above the surrounding terrain. The summit surfaces of these ridges display either exposed heavily weathered bedrock with weathering pits up to $10 \mathrm{~cm}$ deep and frequent tors and microtors, or a thin cover of
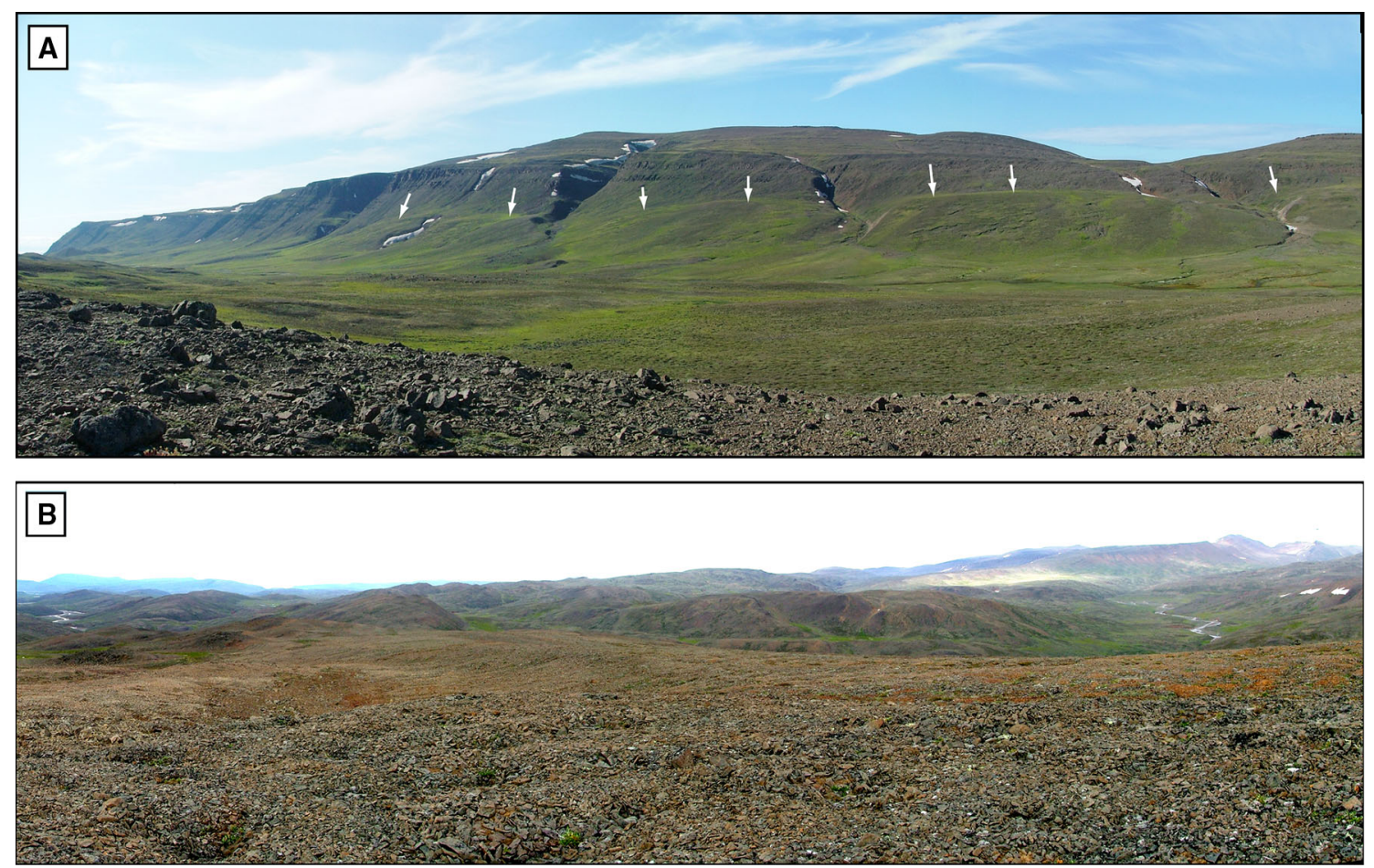

Fig. 5 Photographs of the general morphology of the Quagssugaarsuit region. a Photograph looking westward across the low-lying Quagssugaarsuit valley. The higher ground in the background rises steeply to $\sim 400 \mathrm{~m}$ a.s.l. and has distinct trimline/drift limit halfway up its face (arrowed). Arfertuarssuk fjord head is to the far left of the photograph; b heavily weathered and frost shattered terrain $>300 \mathrm{~m}$ a.s.l., with a well-developed fluvial system in the lowlands to the left and right of the photograph 
weathered regolith, generally angular autochthonous blockfield with some abraded, subrounded erratic clasts. Where present, the regolith has been subjected to extended periods of periglacial processes including frost shattering and stone sorting (Fig. 5b). Very occasionally weathered bedrock surfaces display fragments of glacial polish and striated faces. Infrequent subrounded boulders of local basaltic and far-travelled gneissic lithologies are present up to $400 \mathrm{~m}$ a.s.1., perched upon the present land surface. Above this elevation subrounded boulders become far less common. A number of the NNW-SSE bedrock ridges within the Quagssugaarsuit valley are incised deeply by meltwater channels. The channels are short but deep features (up to $10 \mathrm{~m}$ ) and appear to cut across local watersheds, forming at ridge interfluves, with no clear meltwater source area. Low-lying regions between the bedrock ridges contain well-developed fluvial systems, draining either north-north-west or south-south-east. Clasts within these channels are dominated by local basaltic lithologies, although infrequent gneissic erratics were found, increasing in abundance to the north-east of the valley.

A small lobate ridge was mapped on the east of Quagssugaarsuit, close to the mouth of the Akulerqut Valley. It is $\sim 2-3 \mathrm{~m}$ high, $5 \mathrm{~m}$ wide and only present on the southern side of the valley. Based upon its morphology and position upon the flank of the valley, the ridge is interpreted as a partial remnant of a lateral moraine, sourced from local glaciers. A small (0.5-1 m high), discontinuous ridge was mapped $500 \mathrm{~m}$ up-valley of the moraine, close to the present fluvial channel. It was formed of subrounded cobble-sized, locally derived basaltic clasts. On the basis of its mid-valley position, internal sediments and morphology, this is interpreted as an esker, as defined above [5, 89].

\section{Kugssineq and Tasiussaq (Logs 5-9)}

East of Arfertuarssuk, the south coast of Svartenhuk Halvø contains five north-south trending valleys, sourced from the higher elevation ( $>1000 \mathrm{~m}$ a.s.l.) interior. These valleys are fed by a number of individual, small $\left(<3 \mathrm{~km}^{2}\right)$ outlet glaciers and have large, U-shaped cross-profiles up to $5 \mathrm{~km}$ in width. Valley floors are characterised by contemporary tidal flats, salt marshes and misfit fluvial streams. All valley systems were seen to contain thick sequences of sediment close to the valley mouths, extending up to $3 \mathrm{~km}$ inland [46]. These sediments form flat-topped fans and deltas, grade to heights of between 14 and $43 \mathrm{~m}$ a.s.1. and are bisected by contemporary misfit fluvial systems.

The two most westerly of these valleys are Kugssineq and Tasiussaq (Figs. 2, 6). The Kugssineq valley is a 0.8$\mathrm{km}$-wide, flat-bottomed valley containing a contemporary salt-marsh system. A series of sediments were preserved at the mouth of the valley in a large, flat-topped delta, reaching $18 \mathrm{~m}$ a.s.l. The floor of the Tasiussaq valley is characterised by contemporary salt marsh, with a number of large circular pools (Fig. 7c). These features were not studied in detail in the field, but their circular morphology and the presence of other glacial features in the valley suggest they are submerged kettle holes, and the valley floor represents a kettled sandur plain [65]. Two discontinuous, arcuate ridges were mapped on the south side of the valley, between Tasiussaq and Igdlerussat qáqâ valleys (Fig. 7b), running subparallel to Tasiussaq valley long axis (NE-SW) (Fig. 7b, c). They are wide and low in relief ( $<10 \mathrm{~m}$ wide, $<4 \mathrm{~m}$ high) and formed of angular to subrounded clasts between pebble and boulder size, and are interpreted as inset lateral moraines [5, 16], relating to the presence of ice within the Tasiussaq valley, sourced from the Svartenhuk interior (Fig. 8).

High-elevation terrain outside of these moraines is characterised by frost shattered bedrock, with a thin, patchy cover of weathered regolith (Fig. 8c). Where bedrock remains intact and exposed, outcrops displayed weathering pits up to $6 \mathrm{~cm}$ deep and occasional abraded and striated surfaces (orientation $173-353^{\circ}$ ). Only basaltic erratics were found on this terrain. The mapped extent of this weathered surface is shown in Fig. 6, although based upon field observations it is likely that this type of surface covers the majority of high-altitude areas ( $>500 \mathrm{~m}$ a.s.l.). Terrain inside of the lateral moraine complex is dominated by fluvial and salt-marsh environments. Bedrock surfaces appear less weathered than terrain outside of the moraines, with weathering pits commonly $1-2 \mathrm{~cm}$ in depth. Sediments at the mouth of Tasiussaq valley (Fig. 7c) are best preserved on the southern side of the valley, in a flat-topped delta sequence graded to $16 \mathrm{~m}$ a.s.l. (close to the neighbouring Igdlerussat qáqâ; Figs. 6, 7c). A series of low-relief, sinuous, ridges occur on these flat-topped deposits and are interpreted as eskers [5, 89]. They are orientated subparallel to the Tasiussaq valley and lateral moraines found on higher ground to the south (Fig. 8a, b). A large, sedimentary mound also occurs in south-west Tasiussaq, south-west of the delta $(\log 9)$, and measuring $120 \mathrm{~m}$ long by $20 \mathrm{~m}$ high. The feature lies below a small valley sourced from high ground to the south-east, close to Igdlerussat qáqâ and is clearly glacially streamlined.

\section{Uligssat (Log 10)}

Uligssat is the easternmost of the Svartenhuk Halvø valleys (Fig. 2). Extensive sediments are preserved close to the valley mouth and further up-valley in a series of inset deltas and alluvial fans, graded to between 20 and $75 \mathrm{~m}$ a.s.l. The highest altitude feature in the valley at $75 \mathrm{~m}$ a.s.l. 
Fig. 6 Geomorphological map of the Kugssineq valley and Tasiussaq region showing deposits and landforms mapped during this study. Sites are labelled with numbers referred to in the text

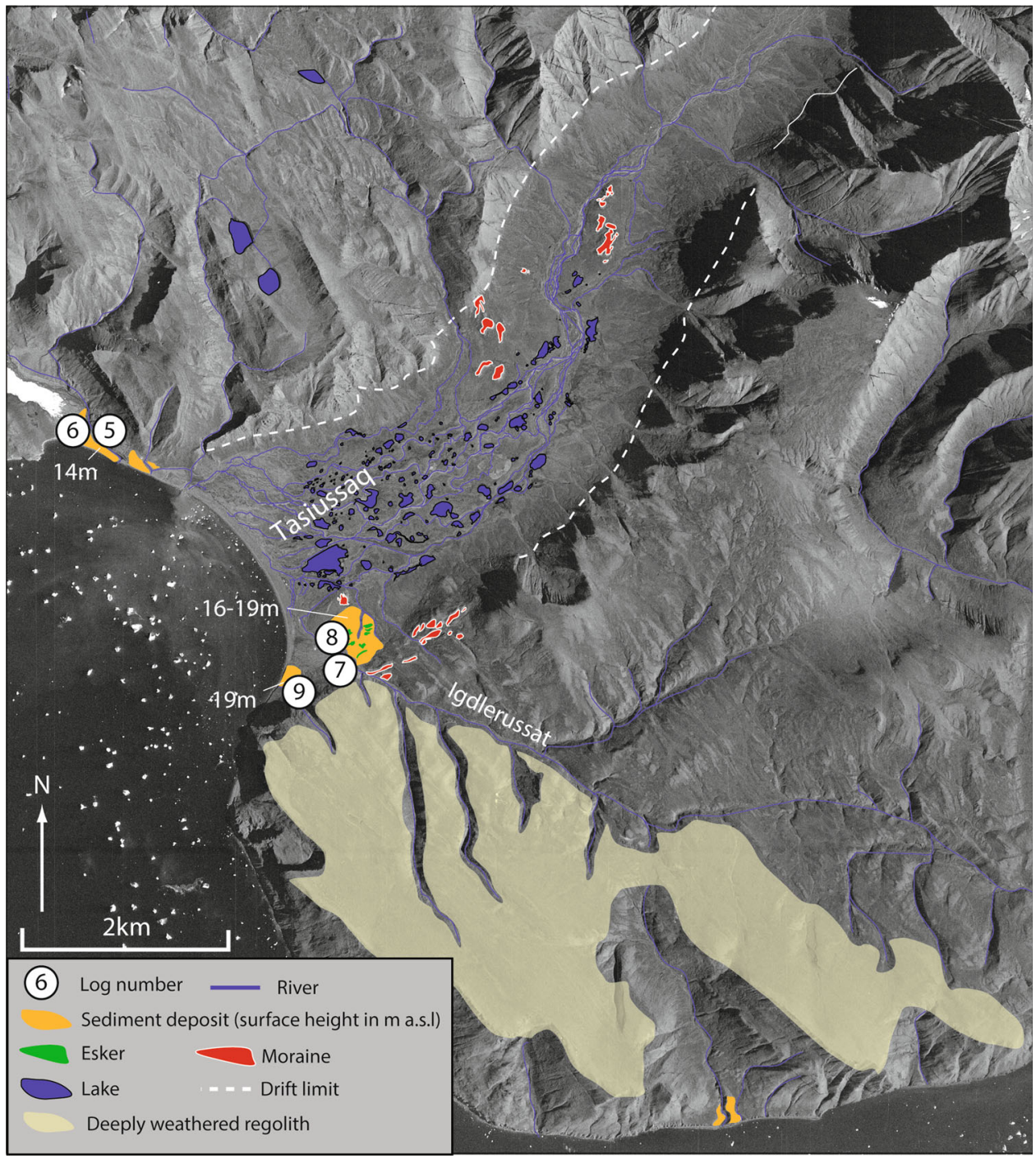

appears as an alluvial fan, emanating from a small $\left(0.25 \mathrm{~km}^{2}\right)$ bench incised into the bedrock valley wall, backed by a small bedrock incised cliff. This bench is the highest evidence for marine activity throughout the Svartenhuk Halvø area and likely represents a marine limit. A large delta complex is found close to the mouth of the valley, dissected by post-depositional fluvial and coastal erosion, with a series of subangular to subrounded erratic quartzite boulders resting upon its surface (Fig. 9). This delta is flat-topped, with a gentle surface slope, and steeply dipping up-valley face (Fig. 9). The surface of the delta reaches $36 \mathrm{~m}$ a.s.l. at its highest point, dropping to $\sim 24 \mathrm{~m}$ a.s.l. at its down-valley edge. A section was logged from the large delta at the mouth of the valley $(\log 10)$. Tributary fluvial channels up-valley feed into a series of alluvial fans. Kame terraces, poorly formed discontinuous lateral moraines, and a drift limit are also evident on the valley walls.

\section{Sediment descriptions}

As a lithofacies approach was adopted for sediment description and interpretation [27, 28], the sediments from southern Svartenhuk Halvø have been subdivided into five distinct lithofacies associations (Table 3). Several of these lithofacies associations were further subdivided in order to fully characterise the sediment. Clast fabric data are shown in Figs. 10 and 11, and sedimentary $\operatorname{logs}$ are shown in Figs. 12, 13 and 14 .

\section{LFA1}

LFA1 is a diamicton containing angular to very angular, locally derived basaltic clasts held within a clay to silty sand matrix. It occurs in Log 5 at the edge of the Kugssineq valley valley (Figs. 2b, 6, and 12). The diamicton has bands of altering colour, varying between layers of red, brown, 

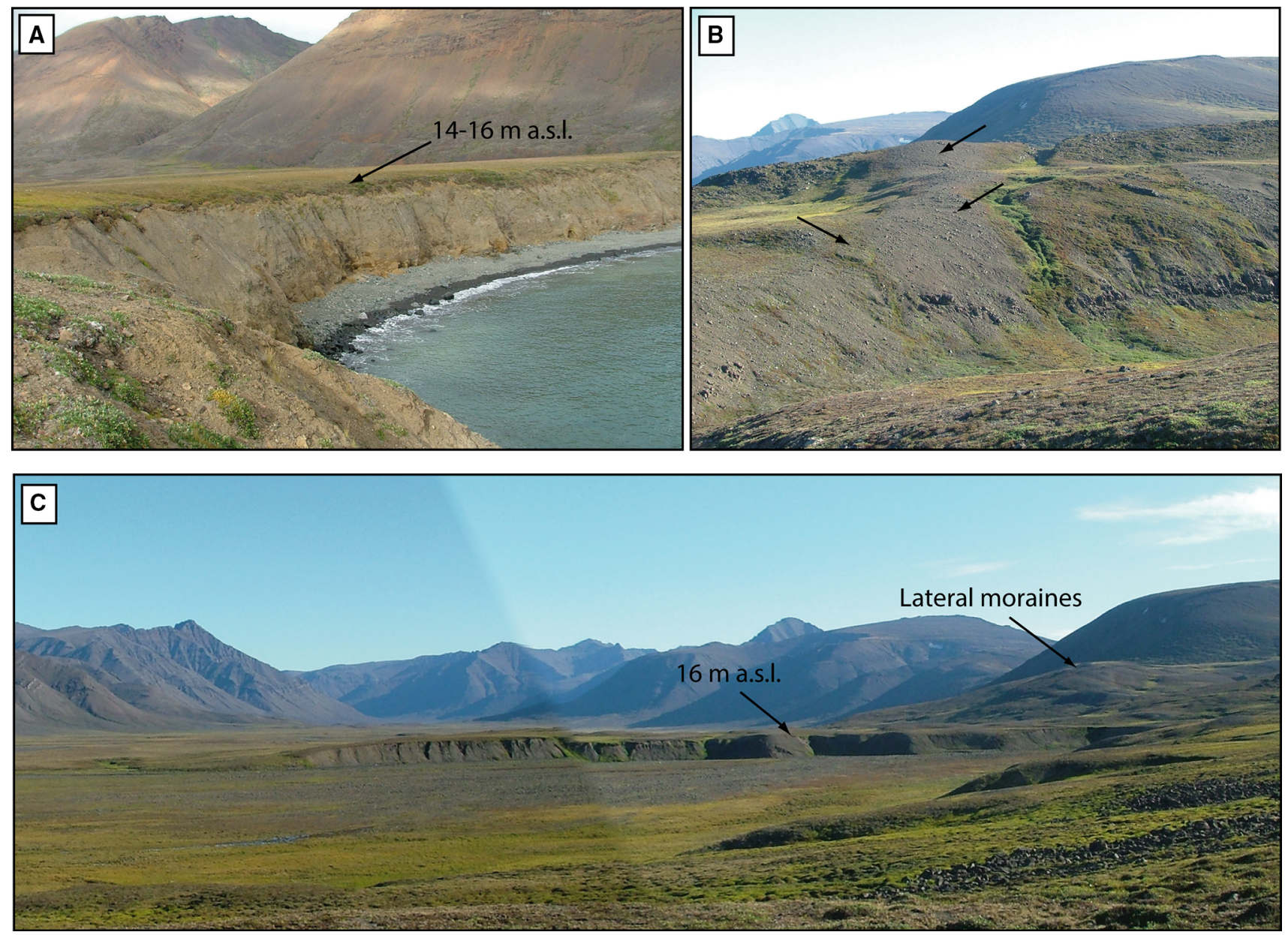

Fig. 7 Photographs from the Kugssineq and Tasiussaq valleys. a View looking east at the cliff exposure of the delta at the mouth of the Kugssineq valley, the surface of which is graded to $14-16 \mathrm{~m}$ a.s.l. Logs 5 and 6 were taken from this exposure; b view looking north-east of the largest inset lateral moraines on the southern border

yellow and purple. Clast density throughout this lithofacies is variable and in places the diamict is clast-supported. The majority of clasts show a high degree of weathering and extensive brecciation. LFA1 was seen to be transitional into, or interstratified with, in situ bedrock breccias with a higher clast density and in places partially intact primary bedrock structures (Fig. 15). The in situ bedrock appears to have been displaced or thrust, with the coarse, angular, diamict found between areas of heavily brecciated bedrock.

The brecciated bedrock of lithofacies association LFA1 is interpreted as heavily weathered, glaciotectonised in situ bedrock and is indicative of overriding by grounded, warmbased glacier ice. Periglacial modification would have occurred initially during an extended cold-climate condition, but bedrock brecciation is likely to have been caused by ground ice development [66]. However, the interfingering of zones of brecciated bedrock with bedrock-rich diamicton (Figs. 12, 15) suggests bedrock disturbance of the Tasiussaq valley; c view of the Tasiussaq valley, looking northeast, up-valley. The obvious flat-topped feature in the centre is a delta, graded to $16 \mathrm{~m}$ a.s.l. Logs 7 and 8 were taken from the exposure facing the camera. In addition, inset lateral moraines can be seen to the right of the image

through glaciotectonism under a warm-based ice mass [42, 71]. The transition from undeformed bedrock (via heavily brecciated bedrock) to a clast- to matrix-supported diamict is a result of a switch to subglacial conditions through time $[10,21,50]$. The diamictic lithofacies both above the bedrock (and in places interstratified with it) is produced by more intense glaciotectonic processes, including bedrock crushing and mixing with fine rock flour $[39,50]$. The lowermost bedrock varies between intact and brecciated, and is the result of minor glaciotectonic activity.

\section{LFA2}

LFA2 is a grey, poor- to well-consolidated, generally structureless, matrix-supported diamicton with occasional discontinuous lenses of well-sorted sandy silt $(\sim 10 \mathrm{~cm}$ thick, $\sim 30 \mathrm{~cm}$ wide). It occurs in $\operatorname{logs} 1,2,5,6$ and 9 in Arfertuarssuk and Tasiussaq valleys (Figs. 3, 6 and 12). 

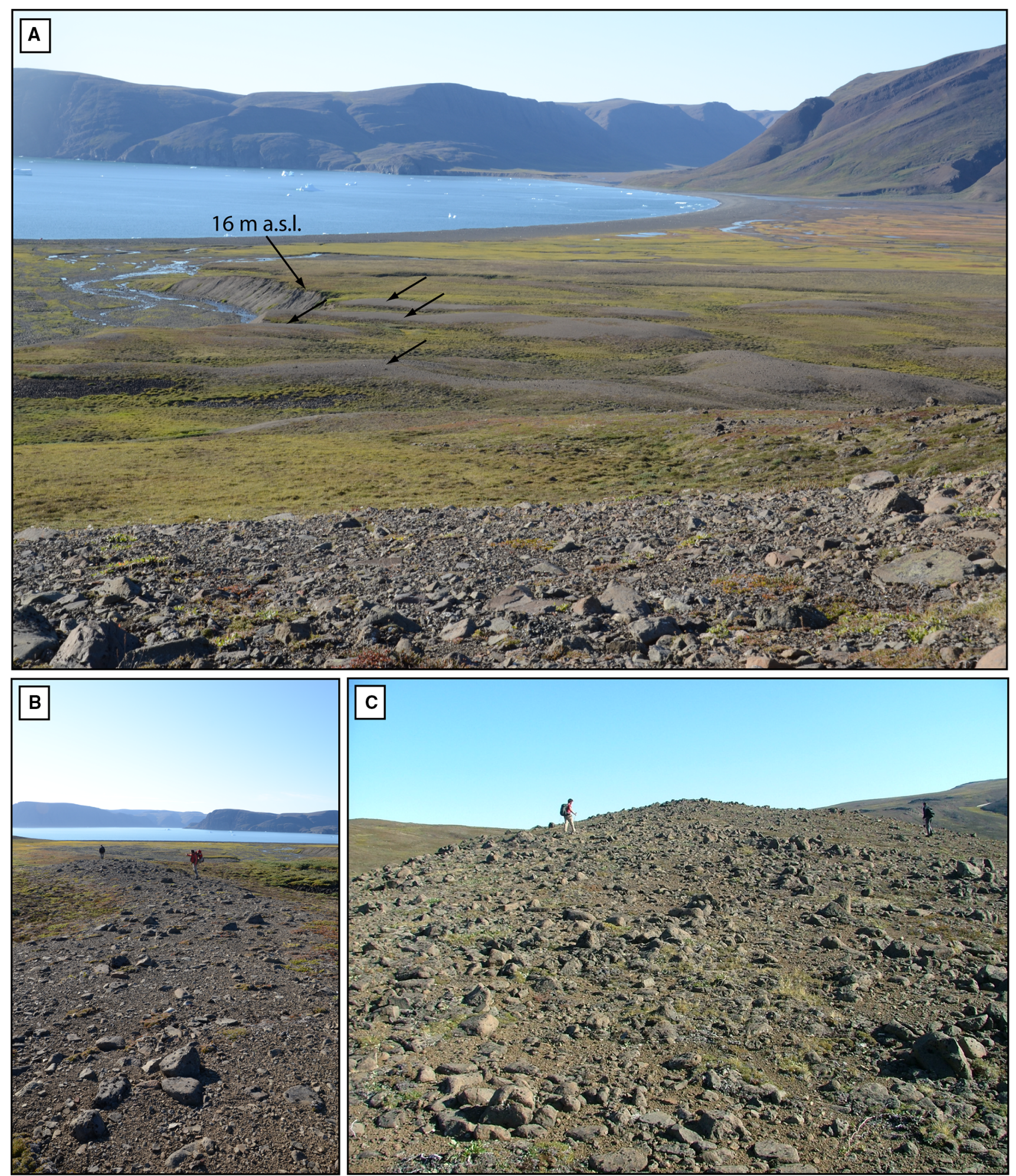

Fig. 8 Photographs from Tasiussaq valley a oblique view looking north-west over the delta surface from which Logs 7 and 8 were recorded. Small sinuous graveliferous ridges are indicated by black arrows, trending from right to left across the photo. These are interpreted as eskers (see text for details); $\mathbf{b}$ view along a sinuous, low relief gravel esker overlying Site 7; c typical terrain outside the Tasiussaq lateral moraine limit-extensive heavily weathered regolith 

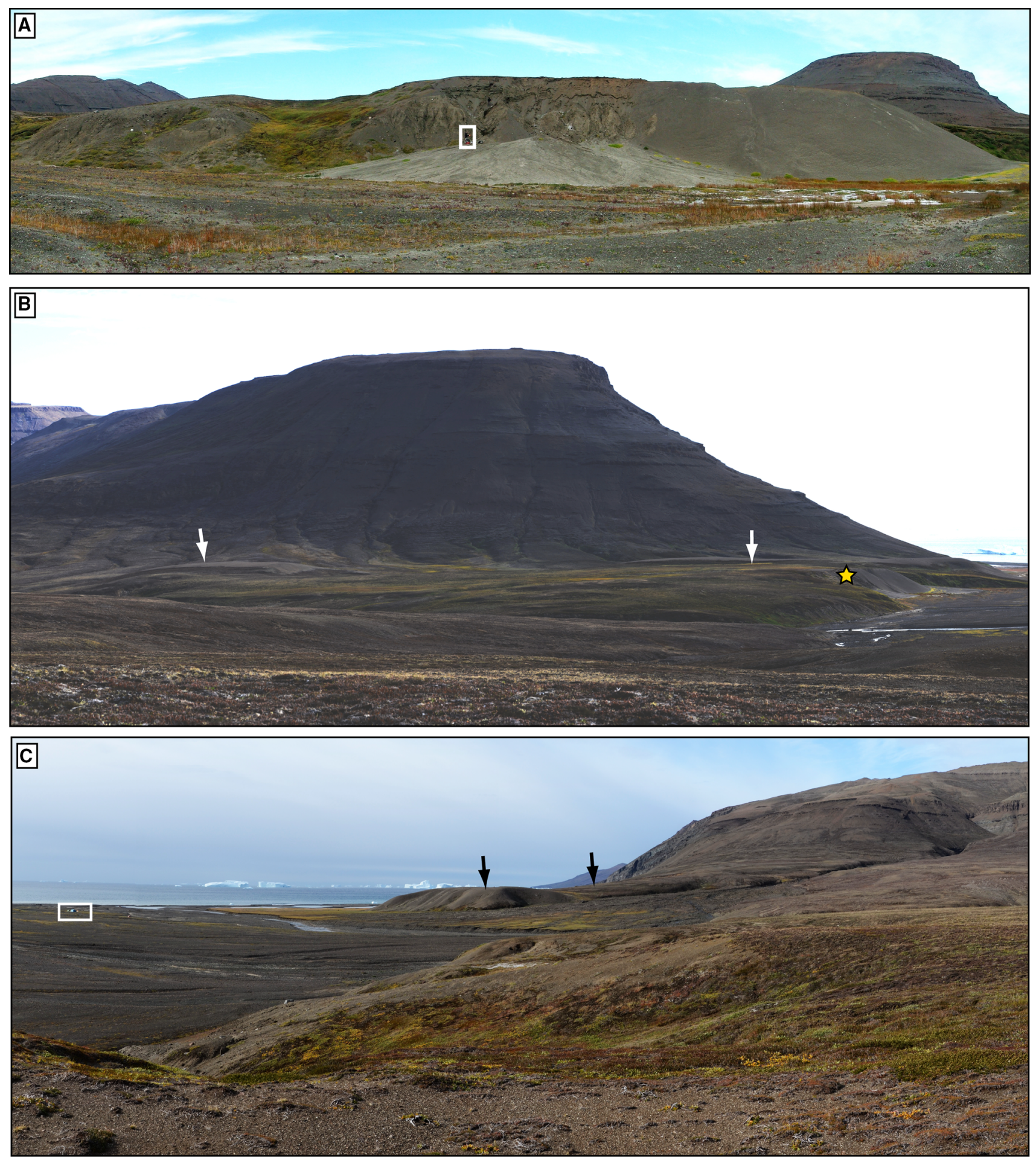

Fig. 9 Plate of photographs from the Uligssat Valley (see Fig. 6, 3 for valley location). a Photograph looking up-valley at the face of the delta, including the section logged in Log 10. A person can be seen surrounded by a box in the centre of the photograph for scale; $\mathbf{b}$ view looking east towards a raised delta (arrowed) in the mouth of the Uligssat valley. Location of $\log 10$ is shown by a star; c view westward from the delta surface seen in photograph (c). A continuation of the logged delta surface is seen arrowed in the background. The area between the two surfaces is dissected by contemporary fluvial activity. Tents identified by a white box can be seen on the flat fluvial surface to the left for scale 
Fig. 10 Clast form (triangle plots) and clast roundness (histograms) from a number of sites in the study. The specific facies of each sample location is marked, with the facies code
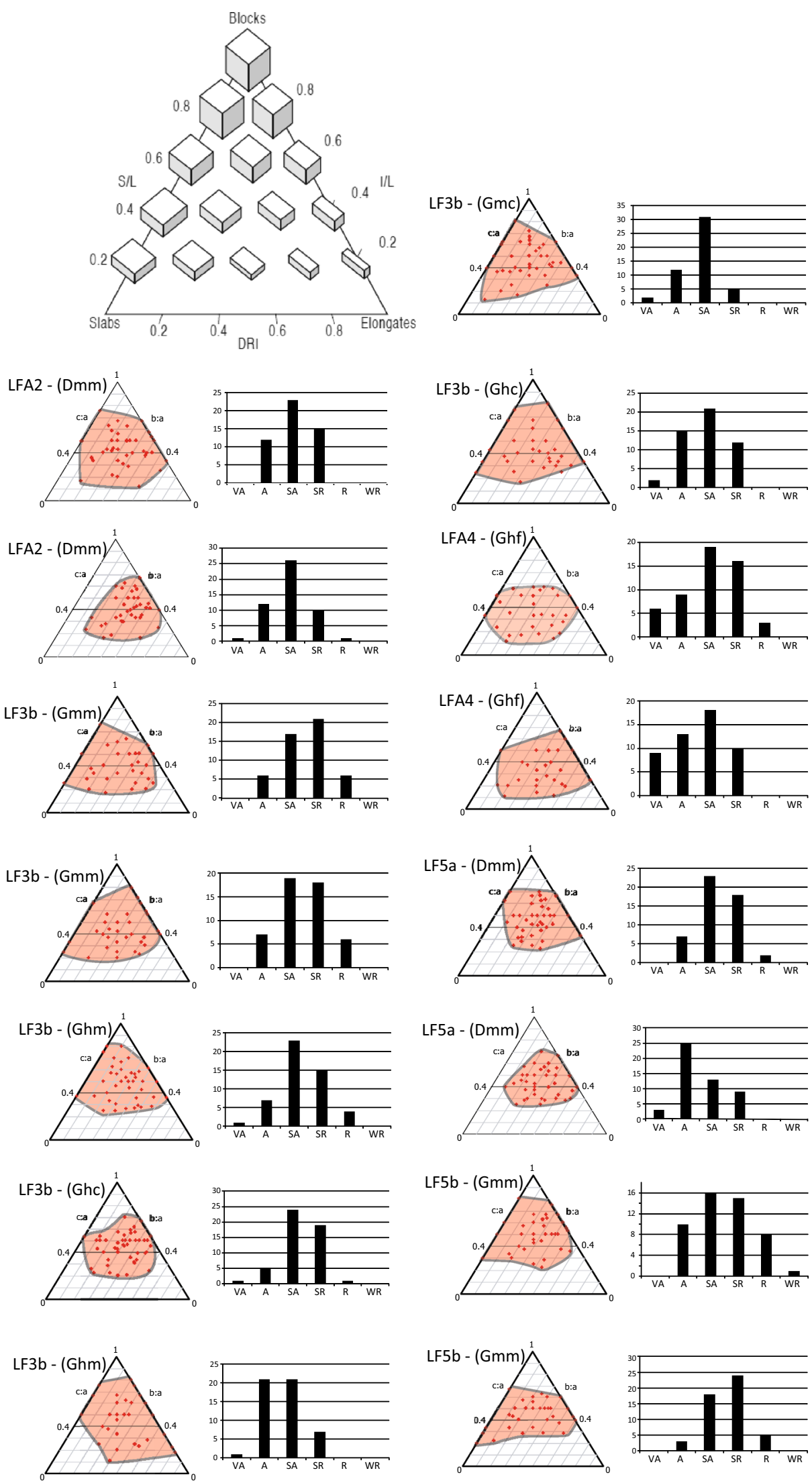

LF5b
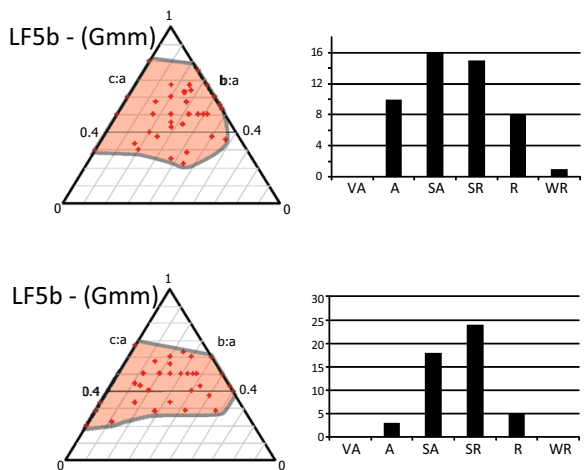

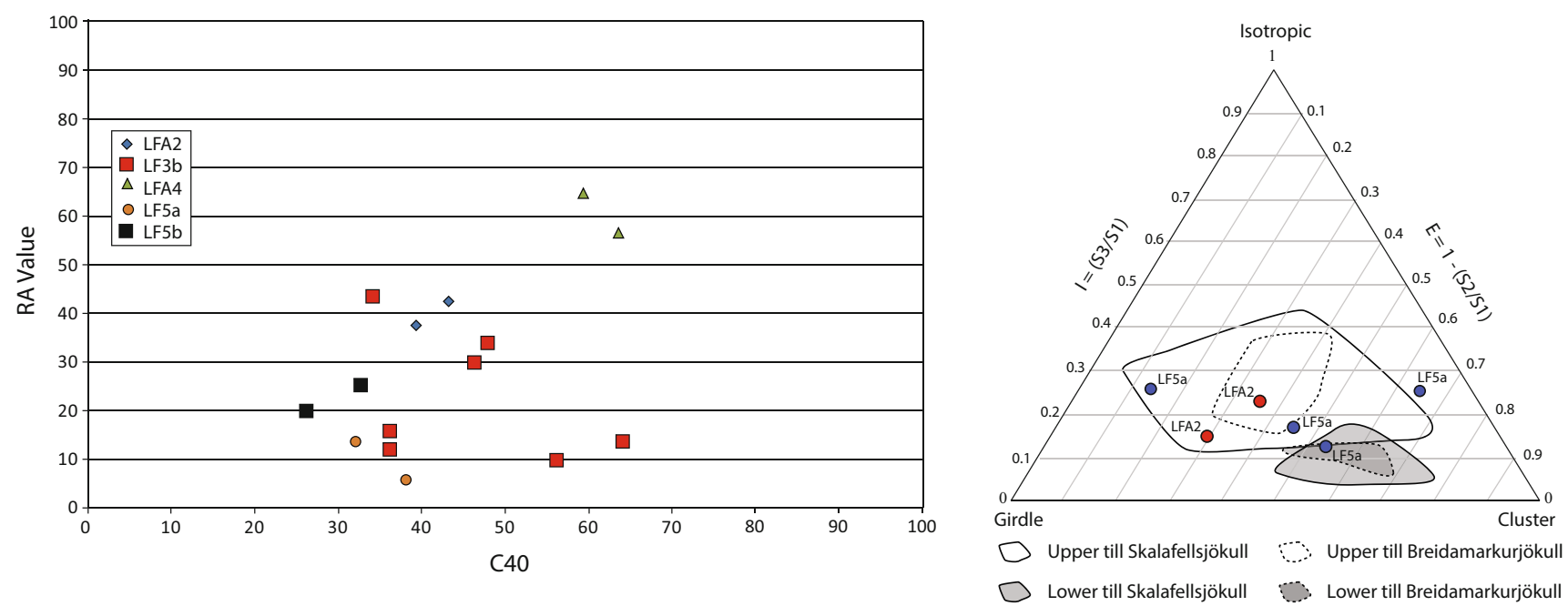

Fig. 11 Plot of clast form data from this study, showing RA values against $\mathrm{C} 40$ values for all samples, with lithofacies codes labelled. Also, clast fabric triangle of samples from LFA2 and LF5a taken

Some very crude stratification was visible in some sections (e.g. facies 5c). Clast abundance is highly variable although the diamict remained matrix-supported throughout. The matrix is composed of silt to silty sand, with particle size peaks at 1000, 150 and $60 \mu \mathrm{m}$. It contains abundant marine shell fragments, dominated by Hiatella arctica and Mya truncata and occasional single valves, although very rare paired valves were found. Clasts are up to $50 \mathrm{~cm}$ in diameter, angular to subrounded, often striated and dominated by local basaltic lithologies and occasional gneissic erratics. Clast form data reveal a preference towards blocky to elongate clasts, with $\mathrm{C} 40$ values between 38 and $44 \%$, and RA values of 37-42. Clast macrofabrics display NWSE-orientated a-axes, with a subsidiary perpendicular, NESW component (Fig. 10). S1 values are 0.54, suggesting moderate a-axis clustering, and fabric shapes plot as girdles to moderate clusters (Figs. 10, 11). A-axes dips vary considerably. Striae were measured on boulders found lodged within LFA2, $\sim 100 \mathrm{~m}$ to the south-west of $\log 1$. Results showed highly uniform intra-boulder striae, but high interboulder variability, suggesting boulder rotation during emplacement (Fig. 12). A paired valve from LFA2 in Arfertuarssuk ( $\log 1)$ returned a finite radiocarbon age of $44,097 \pm 1117{ }^{14} \mathrm{C}$ yrs BP (Table 4).

LFA2 displays many sedimentological, structural and clast properties of a hybrid subglacial till, formed through deformation and lodgement [30]. These include a poor- to well-consolidated diamictic matrix, with subrounded, lodged, striated clasts. The thick nature of LFA2 (up to $5 \mathrm{~m}$ ) may be due to lodgement and reworking of pre-existing sediment, including till $[26,30]$, or due to ice-marginal processes (folding, thrusting and stacking), which lead to till thickening [29, 70]. It is possible that the during this study (red circles), superimposed upon known fabric data from previous studies [6]

massive, structureless nature of LFA2 is due to sediment homogenisation through high levels of strain and sediment mixing $[17,86]$, or is partially inherited from pre-existing sediment. Clasts are all local basaltic lithologies, suggesting glacial erosion and incorporation of basaltic bedrock from the Svartenhuk Halvø interior into LFA2, prior to emplacement. The presence of abundant shell fragments throughout the facies suggests the glacier reworked preexisting marine sediment during till genesis. The occasional stratified elements with the diamicton could represent a remnant element of pre-existing structure within the sediment preserved despite progressive subglacial homogenisation through mixing [30, 70].

Clast fabric data support the interpretation of LFA2 as a subglacial till. The data show low isotropy and variable elongation, falling within known envelopes of upper till fabric, suggesting clast emplacement through lodgement and non-solid-state deformation [6, 11]. In places, clast fabric data are highly bimodal (see Log 2; Fig. 12), with a secondary modal peak transverse to the direction of ice flow reconstructed from bedrock striae evidence. This bimodality could be the result of a localised increase in lodgement, aligning clasts transverse to flow $[1,58]$, or could be the result of weak deformation $[48,49]$. Given the multimodal fabric from Log 1 (LFA2), the latter appears more likely. The clast fabric data suggest ice flow from the

Fig. 12 Sedimentary Logs 1-4, recorded from Arfertuarssuk Fjord and Logs 5-8 from Tasiussaq Valley. Facies codes and sediment symbols outlined to the left are used throughout the chapter. Clast fabric directional data are shown in red stereonets. The inset box for $\log 2$ shows results of striae found on boulder from LFA2. Dated samples given as ${ }^{14} \mathrm{C}$ Kyrs BP 


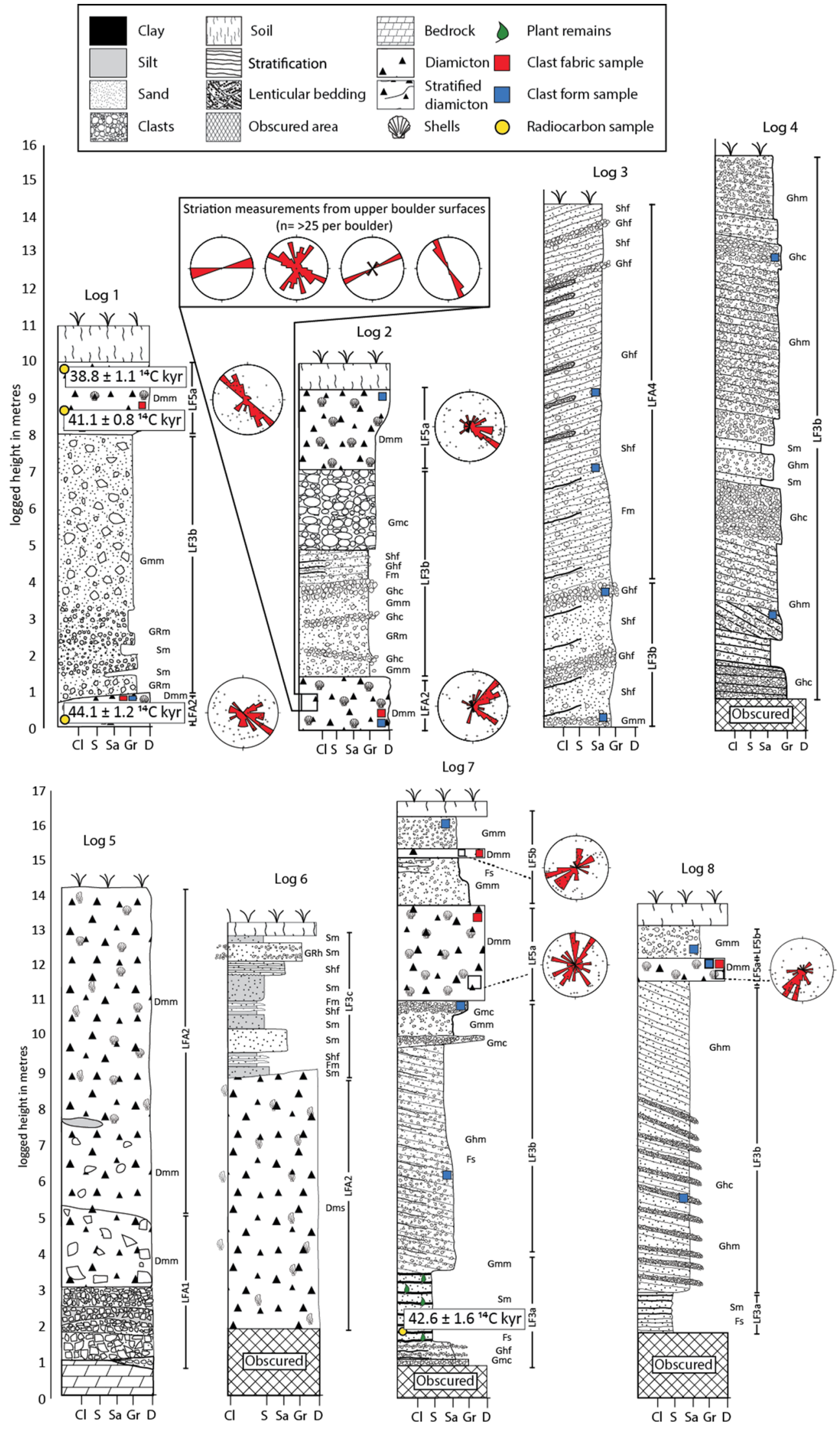


Fig. $13 \log 9$, from the mouth of Tasiussaq (see Fig. 6, 3 for location). Photograph to the right displays interlaminated organics and fines interbedded with gravels in LFA3a. Dated samples given as ${ }^{14} \mathrm{C}$ Kyrs BP. A penknife (12 cm long) is shown for scale
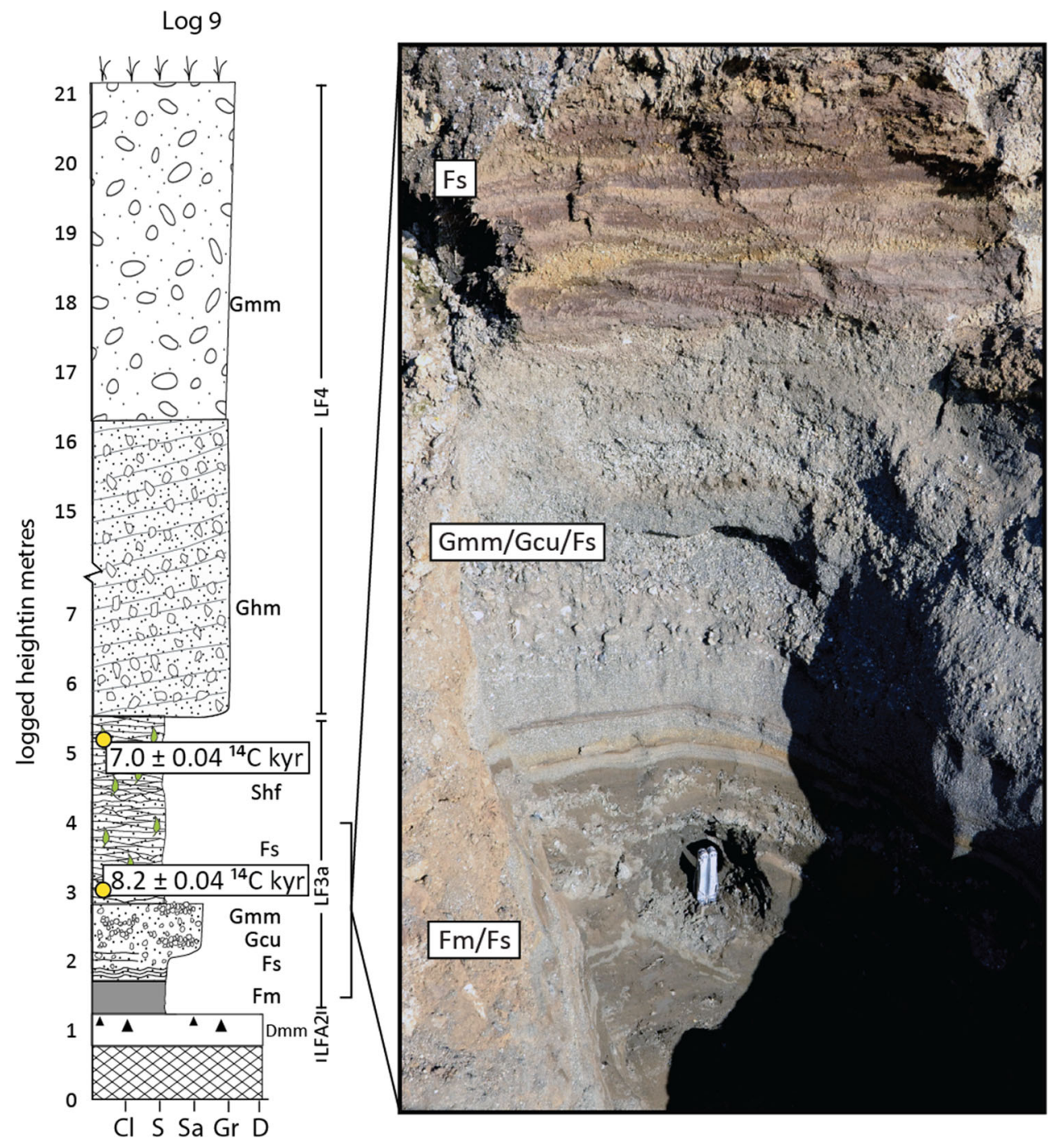

north-north-west, in agreement with striae data from bedrock within the fjord. The relatively weakly clustered clast fabrics suggest ductile deformation similar to the upper A horizons of tills in Iceland [30]. In places clast fabrics show little preferential orientation and a-axes dip does vary from high to low. This is likely to be a result of a localised decrease in the strain experienced by the sediment [7] or a function of the thick deforming layer [43]; alternatively this fabric element could be inherited from the reworked, pre-existing marine sediment (e.g. rainout). Clast form covariance data reveal a relatively angular clast assemblage (Figs. 10,11), suggesting a short clast transport distance.

\section{$L F A 3$}

LFA 3 was split into three subfacies. LF3a is planar bedded, interstratified silty clay, silt and medium sand (Fig. 16), with a fine gravel content (average grain size
$300 \mu \mathrm{m})$. LFA3a is found in $\operatorname{Logs} 7,8,9$ and 10 in Tasiussaq and Uligssat valleys. Planar stratification was horizontal, except for $\log 9 \mathrm{~b}$, where bedding dips west at $2^{\circ}$. Clast-supported gravel horizons up to $60 \mathrm{~cm}$ thick were found, held within a medium sand. LF3a shows evidence of variable grading, displaying normal grading (e.g. Log 7), inverse grading (e.g. Log 9) and no grading (e.g. Log 8). In places finer beds display distinct evidence of post-depositional loading deformation including convolutions, flames and pipes. The silty clay and silt beds contain ubiquitous detrital plant remains, and abundant marine shell fragments and rare whole marine valves were retrieved from fine layers. In $\log 9$ the abundance of macroscopic plant remains increases dramatically between towards the top of LF3a. Here planar-stratified minerogenic silty sand is interstratified with layers of dense mats of plant remains, up to $15 \mathrm{~mm}$ thick. The organic remains were dominated by aquatic reed species and in places macroscopic remains of Salix herbacea and Betula nana. In $\log 7$, organic 
$\log 10$

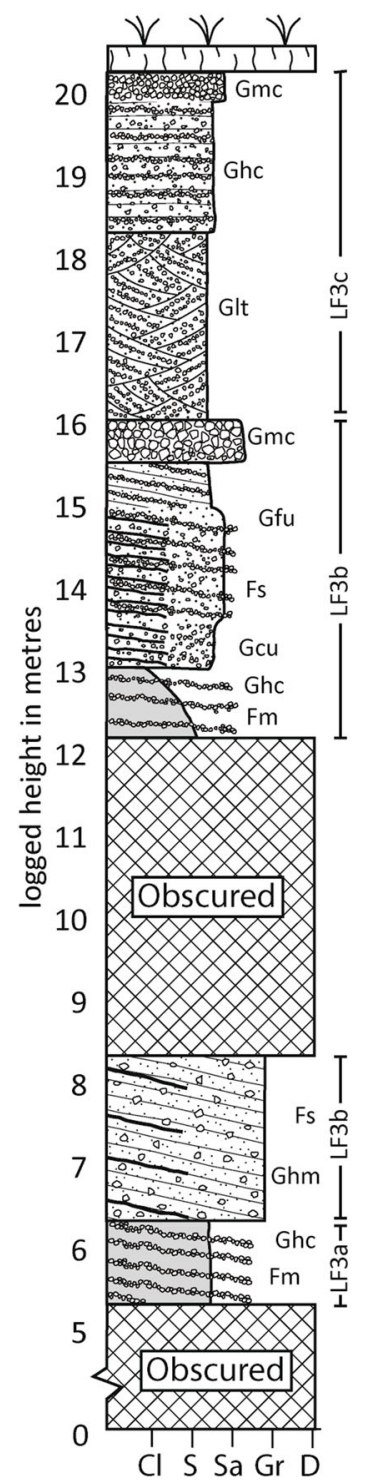

Fig. 14 Sedimentary log and sediment photographs of Site 9, Log A. a dipping, interstratified silts, fine sands and granules; b coarser deposits of sands and matrix-supported gravels, still showing planar stratification; c coarser gravels, in places clast-supported. Some

material in LFA3a returned a finite radiocarbon age of $42,643 \pm 1632{ }^{14} \mathrm{C}$ yrs BP (Table 4). In contrast, in Log 9, organic material in LFA3a returned two much younger radiocarbon ages of $6969 \pm 39$ and $8150 \pm 40{ }^{14} \mathrm{C}$ yrs BP respectively (Table 4/ Fig. 13).

LF3b is an orange-brown crudely to well-stratified matrix-supported sand and gravel, interstratified with thin $(\sim 2 \mathrm{~cm})$ facies of coarse, clast-supported gravel, coarse sand and silt. It occurs in $\operatorname{Logs} 1,2,3,4,7,8$, and 10 in Arfertuarssuk, Tasiussaq and Uligssat valleys. Gravels are planar-stratified, off-lapping to the south-south-east at $6-37^{\circ}$ and in places display a lensate, channel-like planar stratification, some lenticular bedding; d horizontal, planarstratified gravels, with larger clasts than previous facies. A penknife (12 cm long) is shown for scale

morphology (Figs. 14, 16). Interstratified silts often show distinct loading structures: convolution, flames and pipes. Facies thickness varies, with areas of thin $(\sim 5 \mathrm{~cm})$ silty sand facies interstratified with thick $(>30 \mathrm{~cm})$ facies of gravel. The matrix is dominated by coarse to medium sand ( 700-900 $\mu \mathrm{m}$ in Tasiussaq and $400 \mu \mathrm{m}$ in Arfertuarssuk). Pebble- to cobble-sized clasts are subangular to subrounded local basaltic lithologies, with $\mathrm{C} 40$ values of 36-64 \% and RA values of 10-44 (Figs. 10, 11), suggestive of blocky, compact, subrounded clasts. Rare shell fragments were found throughout LF3b, but no whole shells were retrieved. In Log 10 (Uligssat), a $2.5 \mathrm{~m}$ section 

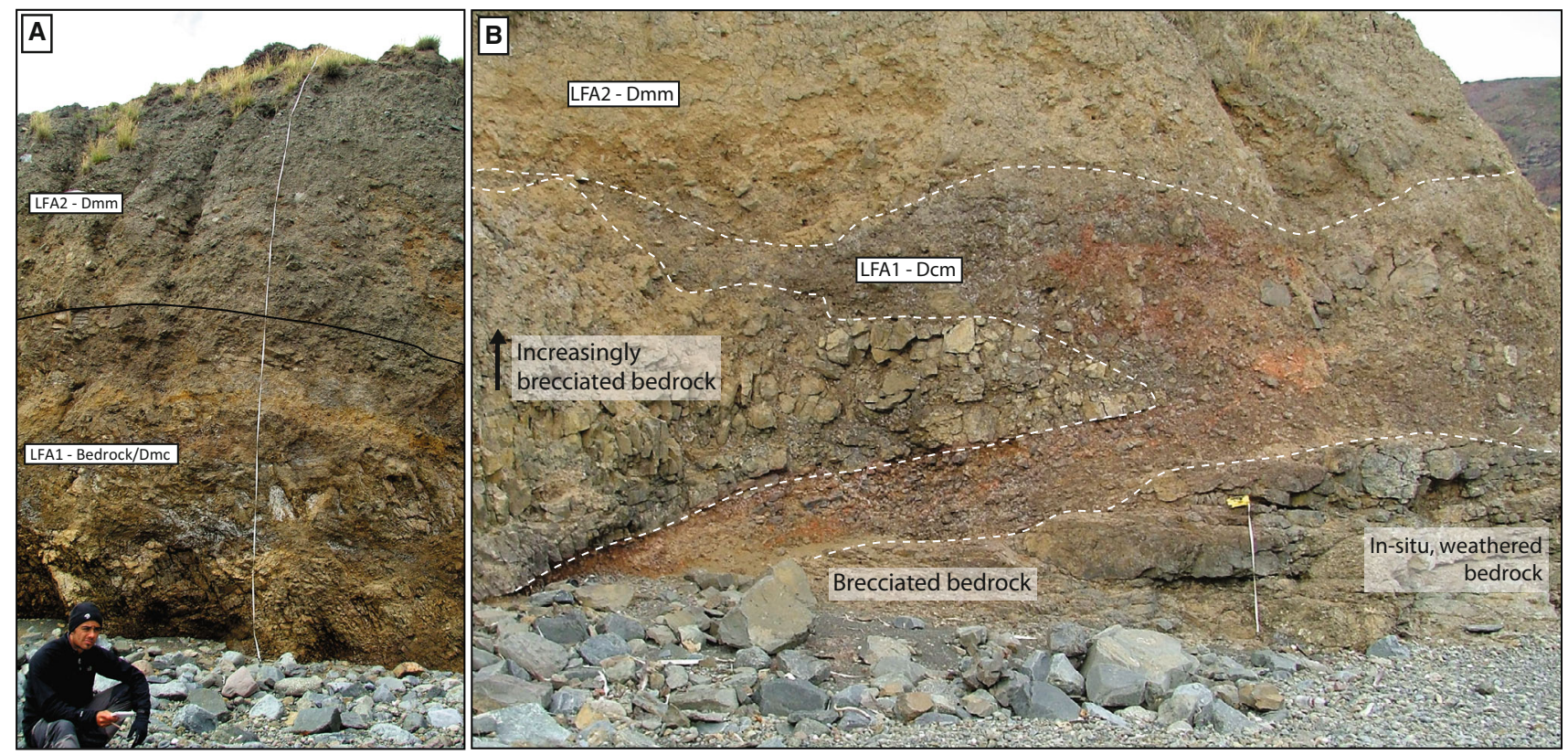

Fig. 15 Photograph from Log 5, showing the only exposure of LFA1. a Overview of the section logged in Log 5; b enlargement of LFA1 and its contact with bedrock below and LFA2 above. The interstratified/injected LFA1 can be seen. Tape measure is $\sim 60 \mathrm{~cm}$ in length

of matrix-supported gravel contained large-scale crosscutting lenticular geometry. In Log 8, LF3b displayed a distinct fining upwards sequence, with a marked reduction in clast size and density, accompanied by an increase in bedding dip.

LF3c is composed of well to very well-sorted interstratified clayey silts, fine to coarse sand, and fine sand and gravel. It occurs in logs 6 and 10 in Tasiussaq and Uligssat valleys. Units are horizontally planar-stratified and up to $50 \mathrm{~cm}$ thick. Granule-sized clasts are local basalt and appear subangular to subrounded. No clast form data were taken from this lithofacies. In Log 10 (Uligssat), a $2.5 \mathrm{~m}$ section of matrix-supported gravel contained well-developed, large-scale cross-cutting lenticular geometry (Fig. 14)

Based upon both their sedimentology (bottomsets, foresets and topsets) and geomorphology (flat-topped features with sloping front and rear faces), landforms formed of LFA3 are interpreted as Gilbert-type deltas [4, 5, 38]. Gilbert-type deltas form in both glacier-fed and ice-contact settings [5] and often display very similar sedimentological properties [60]. The raised deltas from which Logs 4 (centre of the Arfertuarssuk Fjord) and 10 (Uligssat valley) were recorded are distinct features with steeply dipping upstream flanks, lower angle downstream slopes and no upstream continuation. These upstream slopes are interpreted as ice-contact slopes, providing direct evidence that the delta was ice contact during its formation. In contrast, the deltas at sites 1-3, at the head of Arfertuarssuk Fjord, do not display a clear ice-contact slope and are tentatively interpreted as glacier-fed, although kettles holes in upper surface of the delta north-east of $\log 3$ point to localised buried glacier ice. Similarly, the deltas from which Logs 6-9 were recorded do not display clear ice-contact slopes, but do have kettled terrain immediately to the north, suggesting ice was very proximal to the delta complexes.

The fine-grained planar-stratified deposits of LF3a are interpreted as bottomsets of a delta, representing low-energy fluviodeltaic sedimentation [38, 61], deposited by suspended load sediment settling in front of an advancing delta [38, 52, 61]. The ubiquitous macroscopic plant remains are likely to have been introduced from upstream regions through reworking of pre-existing vegetation during glacial advance. The coarsening upwards sequence noted within LF3a suggests a progressive increase in the proximity of the ice margin to the location of deposition.

LF3b is interpreted as a sequence of gravelly glaciogenic delta foresets $[27,38,67]$ deposited in a marine environment. The poor sorting and weak clast imbrication within foreset beds reflect deposition through avalanching, highly concentrated debris flows and bedload deposition down the delta face $[52,72]$. The upward fining sequence recorded in LF3b from Tasiussaq is common sedimentological characteristics of delta foresets [20], representing retreat of the ice margin. In contrast, the exposure of LF3b found at the head of Arfertuarssuk ( $\log 1$ and 2) is characterised by a coarsening upwards sequence. It is possible that this is due to deposition proximal to a glacier meltwater efflux $[3,19]$ or glacier margin advance. The inferred 


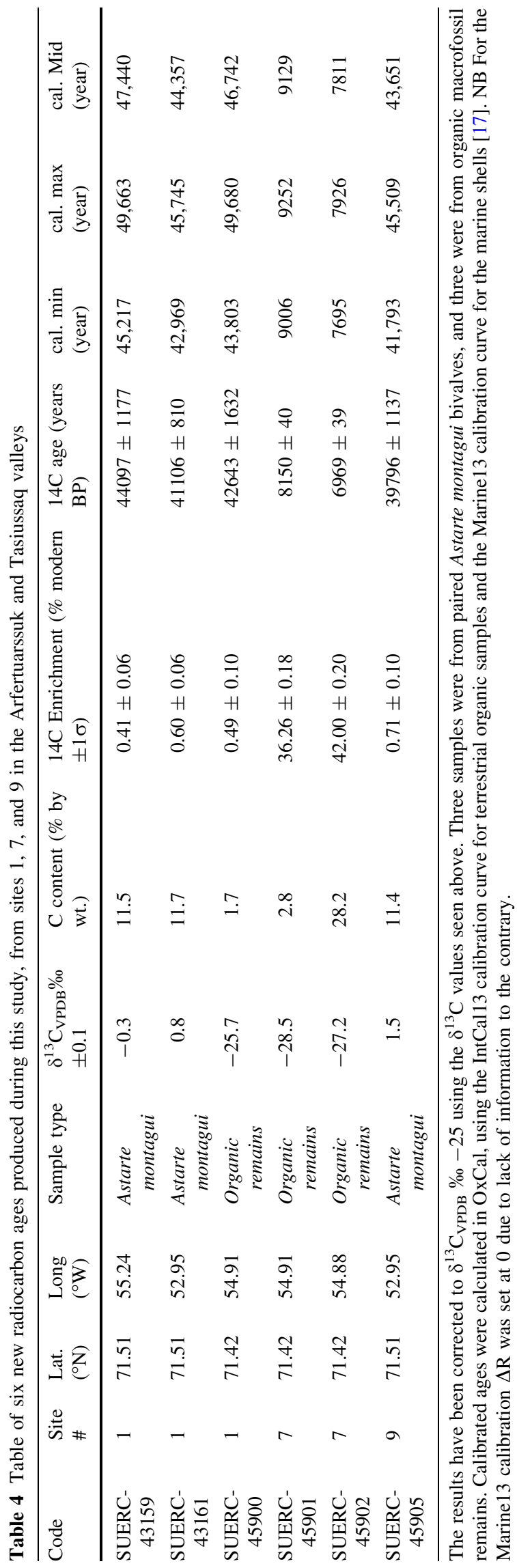

direction of delta formation from foreset dip varies between valleys, with deposition from the north in Arfertuarssuk and Uligssat, and the east in Tasiussaq. Clast form data are variable throughout logged exposures of the lithofacies, but suggest active transport. C40 and RA values are higher than those reported from other deltaic deposits, suggesting a short transport history, and limited clast rounding [9].

LF3c is a massive to planar interstratified silt to gravel and is interpreted as a low-energy glaciomarine/glaciolacustrine/glaciofluvial deposit, formed in the proglacial zone as delta topsets. Variations in grain size and sediment texture are a function of water depth and glacier proximity [36]. The low-energy nature of the sediments suggests deposition occurred in an ice-distal setting. Although LFA3 is found extensively throughout Arfertuarssuk, Tasiussaq, exposure of LF3c is restricted, only found in Logs 6 and 10. The well-developed lenticular geometry of sediments in Log 10 records the development of palaeochannels, a common feature of topset deposits [36, 62], providing evidence for the development of well-defined, channelised flow across the delta surface.

\section{LFA4}

LFA4 is a moderately to poorly stratified, medium to coarse, planar-stratified sand and gravel. It occurs in Logs 3 and 9 in Arfertuarssuk and Tasiussaq valleys. The bulk of LFA4 is matrix-supported, although infrequent facies of clast-supported gravels were logged. Facies from LFA4 dip variably throughout Svartenhuk Halvø: south-south-east at $20-38^{\circ}$ in Arfertuarssuk and west at $8-20^{\circ}$ in Tasiussaq. Gravelly facies in $\log 3$ are interstratified with fine-grained facies of beige sandy silt and discontinuous lenses of brown silty clay. These contain angular basaltic granules up to $3 \mathrm{~cm}$ in diameter. Clasts are local basaltic lithologies, pebble to cobble sized and angular to rounded. The clasts returned C40 values of 60-64\% and RA values of 55-65 (Figs. 10, 11).

Based upon the dipping stratification, and frequent sharp switches between matrix- and clast-supported facies, LFA4 is interpreted as a stratified slope deposit [23, 31]. These deposits are likely to have formed through gravitationally driven slope wash, debris flow and solifluction [14], sourced from steep terrain backing a number of delta sites. Stratification and a clear sorted structure are indicative of an overland flow component [15]. The repeatable pattern of switches between matrix-rich gravel and layers of coarser clast-rich gravel is characteristic of stratified slope deposits, formed through multiple stacked grain flows [88]. Clast form data support this interpretation, with the highest $\mathrm{C} 40$ and RA values reported from this study. The C40-RA plot places the LFA4 samples in a similar region to previously 

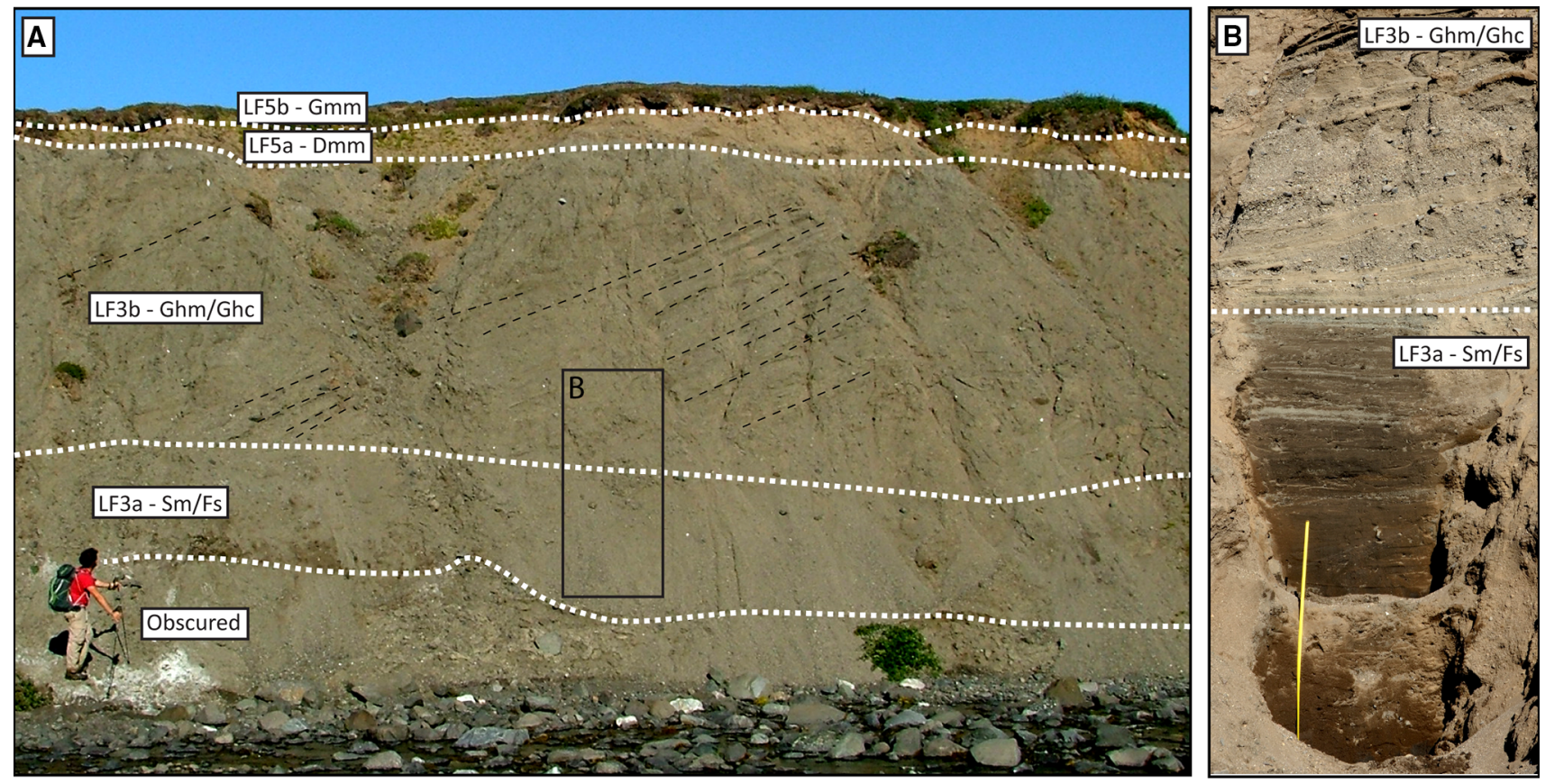

Fig. 16 Photographs from the delta section recorded in $\log 8$. a Overview photograph of the section described in Log 8, dominated by the dipping, planar-stratified LF3b; b enlargement of facies $8 a-b$,

reported scree and supraglacial material [8] (Fig. 11). Such high angularity is characteristic of slope deposits, with a relatively short, passive transport pathway [2, 87, 88]. These data suggest a preference to slabby, elongate forms, also indicative of unmodified, frost-weathered clast [2]. The presence of interstratified fines throughout LFA4 suggests some input through slope wash.

\section{LFA5}

In order to fully describe the sediment variation in observed sites, LFA5 was divided into two subfacies: LFA5a and LFA5b. LF5a is a grey to pink-grey, massive, matrix-supported diamicton. It occurs in $\operatorname{Logs} 1,2,7$, and 8 in Arfertuarssuk and Tasiussaq valleys (Figs. 3, 6 and 12). It is moderately to well consolidated, with a bimodal matrix distribution, with modes at $1000 \mu \mathrm{m}$ (coarse sand) and $45 \mu \mathrm{m}$ (coarse silt). The matrix is rich in marine shells, with common fragments and rare intact in situ single valves. In places the shells occur in distinct horizons. The contact between LFA5 and underlying lithofacies is very sharp with no evidence of sediment mixing. Clasts in LF5a are local basaltic lithologies, up to $20 \mathrm{~cm}$ in diameter and subangular to subrounded, $15 \%$ of which are striated. Clast fabrics are moderately to strongly clustered, displaying low isotropy (Fig. 11). The macrofabric data return an S1 eigenvalue of 0.59 , suggesting moderate to high a-axis clustering and a girdle to moderate cluster clast form shape (Fig. 10). A-axes dips are again highly variable. showing the sharp switch from LF3a to LF3b. A $50 \mathrm{~cm}$ tape measure is shown for scale

Clast form analysis is clustered towards blocky and elongate, and data show C40 values of 38-48\% and a highly variable RA of 6-56 (Figs. 10, 11). As with LFA2, the lithofacies contained abundant marine shell fragments, with very rare paired valves. Two valves from LFA5a in Arfertuarssuk $(\log 1)$ returned finite ages of 39,796 \pm 1137 and $41,106 \pm 810{ }^{14} \mathrm{C}$ yrs $\mathrm{BP}$ respectively $\mathrm{BP}$ (Table 4).

LF5b was recorded capping Logs 7 and 8 in Tasiussaq. This lithofacies is characterised by up to $1 \mathrm{~m}$ of yellow, clast-supported sandy gravel, in places becoming open framework. The facies is generally structureless, with some very crude subhorizontal stratification. In $\log 7$, the gravel is interstratified with occasional lenses $(\sim 3 \mathrm{~cm}$ thick) of well-consolidated pink diamicton, of identical colour, texture and grain size to LF5a. Clasts are local basaltic lithologies, up to $\sim 14 \mathrm{~cm}$ in diameter, and dominated subrounded and rounded clasts. Clast form data show C40 values of 26-32\% and RA values 14-20 (Figs. 10, 11), reflecting an active transport history, either through subglacial or englacial pathways [5].

Based upon its diamictic nature, moderate to strong clustering of clast fabric coincident with independent indicators of ice flow direction and the presence of striated clasts, LF5a is interpreted as a moderately to well-consolidated subglacial till. The presence of local basaltic clasts and shell fragments in subhorizontal horizons throughout LF5a suggests both erosion of the underlying basaltic bedrock and cannibalisation and reworking of pre- 
existing marine sediments. Clast form data display a higher C40 value than previously reported subglacial tills [8], although the low RA values are similar. The high angularity of clasts in comparison with other studies could be due to short transport distance, as in LFA2. Clast fabric data support the interpretation of LF5a as a subglacial till, showing low isotropy and moderate to high elongation, falling within known envelopes of till fabric $[6,11]$. The strength and direction of preferential clast orientation vary between logged facies, but orientation is in agreement with independent ice flow indicators, inferring north-north-west to south-east ice flow in Arfertuarssuk and north-east to south-west ice flow in Tasiussaq. The variable, low to high dip angles could also relate to a fabric derived initially through rainout as with LFA2 [24]. When LF5a is found in association with LFA2, clast macrofabrics from both lithofacies are in agreement, suggesting overriding from similar directions. Fabric from the lower portion of LF5a in $\log 7$ is multimodal, possibly relating to a localised decrease in the strain experienced by the sediment [7], or a function of a thick deforming bed allowing free rotation of clasts $[30,43,48]$, or rainout. The absence of any sedimentary bedding or deformation structures could suggest sediment homogenisation through mixing [86] formatting alternatively could simply be a primary sedimentary characteristic of a partially reworked deposit.

Exposures of LF5b are only found in locations where esker ridges were found forming the upper parts of the section, in logs 7 and 8 from Tasiussaq (Fig. 8) (see "Kugssineq and Tasiussaq (Logs 5-9)" section). As a result, the LF5b sand and gravel are interpreted as esker fill gravel [5, 89] and, importantly, demonstrate ice override of underlying sediment.

\section{Discussion}

\section{Geomorphological and sedimentological evidence for glaciation of southern Svartenhuk Halvø}

Analysis of the interior of Svartenhuk Halvø was limited during this study, but discrete, small-scale evidence of ice activity was evident and includes small, subdued lateral moraines, fragmentary eskers, erratic boulders and overspill channels, the latter formed through drainage of glacierdammed lakes as ice-dammed Arfertuarssuk. Evidence for glacial alteration of land surfaces to the east of Arfertuarssuk and north and south-east of Tasiussaq is present but minor, with erratics and rare striated surfaces above $300 \mathrm{~m}$ a.s.l. Heavily weathered, high-altitude surfaces display evidence of a long-term surface exposure history, suggesting the area has been covered by thin, protective, cold-based ice sourced from plateaux [74]. This protective ice cover is likely to

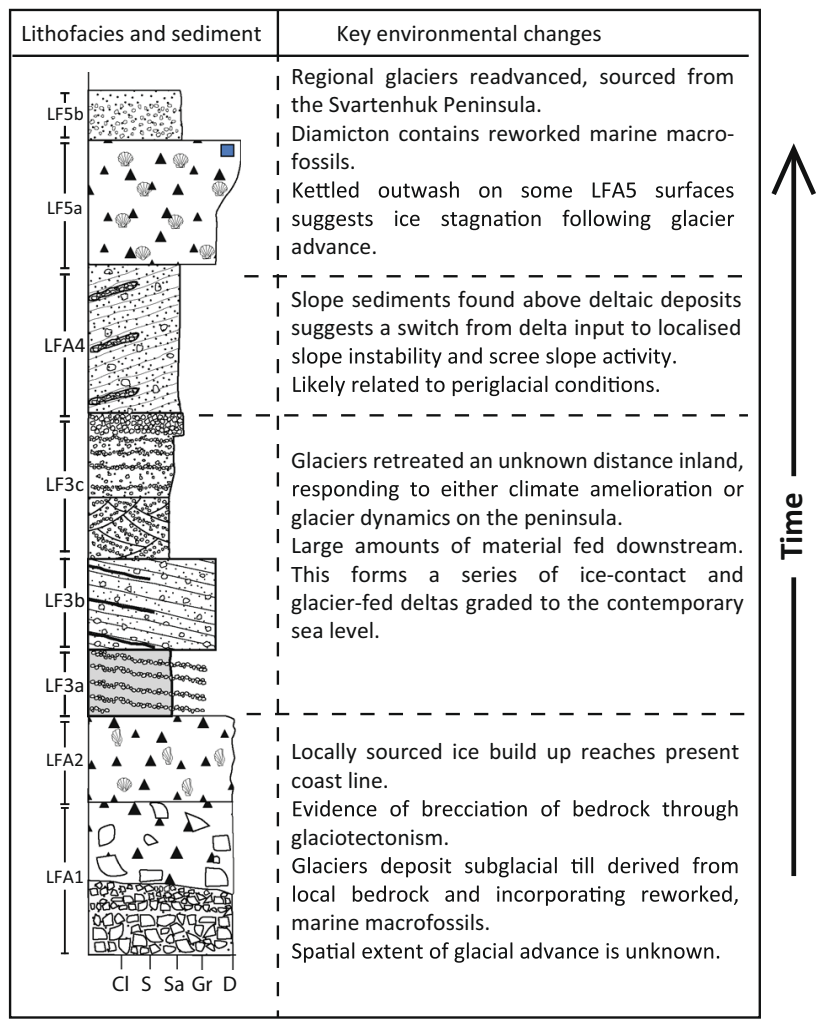

Fig. 17 A composite sedimentary log from the study area

have developed during both the LGM and previous glacial periods, although at present there is no chronological control on the exposure history of the surface.

In contrast, evidence for glacial activity at the coast is incontrovertible (Fig. 17). Glacially striated bedrock at present sea level, lateral moraines, ice-contact deltas, pitted outwash and eskers provide convincing geomorphological evidence for the expansion of locally sourced valley glaciers to the present coastline in Arfertuarssuk, Kugssineq and Tasiussaq. Terminal positions of these glaciers are unknown, although geomorphological evidence constrains them to a position at least offshore of the present coastline. Glaciogenic deltas (both ice contact and glacier fed), eskers and areas of kettled/pitted outwash record the deglaciation of valley glaciers from the coastline. The presence of glaciogenic deltas is suggestive of a retreating glacier front, punctuated episodically by stillstands. The kettled/pitted deltas and outwash systems in Arfertuarssuk and Tasiussaq suggest high sediment flux and meltwater routing of glaciofluvial material to the margin causing the partial burial and stagnation of marginal ice during retreat [5]. This evidence is pivotal in Arfertuarssuk and Tasiussaq as it demonstrates that the construction of the delta features is associated with a period of glacier expansion in the coastal lowlands of Svartenhuk. 
LFA2 and LF5a are interpreted as subglacial tills and found extensively throughout Arfertuarssuk (Logs 1 and 2) and Tasiussaq (Logs 5, 6, and 9), providing direct evidence for grounded, warm-based ice. Further evidence for local glaciation is provided by striated bedrock and sediments displaying evidence of glaciotectonic deformation (LFA1-Log 5). Clast fabric data from LFA 2 and LFA5a, although not displaying high $\mathrm{S} 1$ values, are in agreement with bedrock striae, moraine and delta orientation, suggesting that flow was topographically confined by valley morphology, with ice sourced from the highaltitude centre of the Svartenhuk Halvø, with no input from the GrIS.

The presence of whole and fragmented marine shells (predominantly $M$. truncata and $H$. arctica) in LFA2 and LF5a suggests that the sediments consist of reworked marine sediments though they lack definitive sedimentary criteria diagnostic of glaciomarine deposition [44]. In Arfertuarssuk, the exposure of LFA2 and LF5a is separated by deltaic sediments (LFA3) providing evidence for two distinct ice advances in Arfertuarssuk punctuated by retreat in a raised marine setting between 10 and $14 \mathrm{~m}$ a.s.1. In contrast, although both LFA2 and LF5a are present in Tasiussaq, they do not outcrop in a single stratigraphic section. However, LFA $5 \mathrm{a}$ and $5 \mathrm{~b}$ show clear evidence for ice overrunning lower deltaic sediments (LFA 3a-3c) and emplacing subglacial and esker-derived sediments in a similar stratigraphic position and altitudinal range to the evidence from Arfertuarssuk (16-19 m a.s.1.). Furthermore, the stratigraphic architecture of LFA3 and the presence of whole and fragmentary marine shells and reworked plant fragments in LFA $3 \mathrm{a}$ and LFA $3 \mathrm{~b}$ support Gilbert-type delta formation in a marine setting with glacier advance and meltwater streams reworking preglacial material. Coupled with the overlying subglacial till and eskers at Tasiussaq (LFA 5a and LFA 5b), the geomorphic and sedimentological evidence points to the formation of these landforms during glacial conditions. Similar delta and alluvial fan assemblages from adjacent sites along the coast occur at an altitudinal range between 12 and $75 \mathrm{~m}$ a.s.1., inferring formation of these features during a higher than present relative sea level under glacial conditions.

This set of interpretations contrasts with previous studies that have linked these sediments to elevated sea level during interglacial MIS5e (Svartenhuk Marine Event) based mainly on the analysis of marine mollusc and microfossil assemblages in the sediments around of Arfertuarssuk, Kugssineq and Tasiussaq [13, 51, 56, 83]. Lithologically, Bennike et al. [13] interpreted most of the sites as littoral gravel and sublittoral mud. Diamictons were only described at one site in Arfertuarssuk and interpreted a glaciomarine or solifluction deposits [51]. Bennike et al. [13] concentrated on sampling for faunal and geochronologic analyses, without undertaking a detailed lithostratigraphic, sedimentological and geomorphic appraisal of the sediment/landform assemblages. In contrast, this work has adopted a morphostratigraphic approach and identified reworked glaciomarine/subglacial diamicts, esker and deltaic sediments and pitted/kettled outwash associated with subglacial and ice-marginal landforms situated in glaciated valley settings. Interestingly, Bennike et al. [13] do propose that the diamicts (e.g. LFA 2 and LFA 5a) may be of glaciomarine origin, but they report a molluscan, foraminifera and ostracod assemblage containing both cold and warm marine species [13]. This could support the hypotheses that LFA2 and LFA5a are subglacially reworked diamicts that originated initially as glaciomarine sediments that contained a fossiliferous assemblage of both reworked and in situ cold and warm stage marine fossils, respectively. In summary, we propose that the sediment/landform assemblages from this coast are derived from direct glacial activity. They do not represent in situ interglacial environments deposited following the last deglaciation of this coast and do not appear to represent a coastal assemblage made only of raised spits, cuspate forelands and deltas/alluvial fans.

\section{Chronology of southern Svartenhuk Halvø deposits}

The existing chronology constraining the deposits analysed in this study is based upon a number of infinite radiocarbon ages $\left(>30-40{ }^{14} \mathrm{C}\right.$ yrs BP) from sites close to $\operatorname{Logs} 1,3$, and 5/6 (Table 1), amino acid racemisation determinations, and U-series ages ([90 and $115 \mathrm{kyr}$ BP (no errors quoted) - [34] as from [51]. This led Bennike et al. [13] to assign a MIS $5 \mathrm{e}$ age to the shell assemblages and associated sediments. This study has provided four additional ages from Arfertuarssuk and Tasiussaq ranging between 39796 and 44097 ${ }^{14} \mathrm{C}$ yrs BP (Fig. 12/Log 1 and $\log 7$; Table 4). The potential infinite value of many of the Svartenhuk ${ }^{14} \mathrm{C}$ samples makes a robust validation of the ages of the shell and organic material from LFA2, LFA3, and LFA5 challenging, but the new ages, if considered finite, provide a maximum age for the emplacement of the sediments between 39796 and $44097{ }^{14} \mathrm{C}$ yrs BP. Given the sedimentological evidence presented here, and the faunal assemblages and ${ }^{14} \mathrm{C}$ ages reported by Bennike et al. [13], we, therefore, hypothesise that faunal assemblages are likely to be MIS 3 or older, and deposited in both warm, interglacial and cold, glaciomarine coastal environments. The sediments and faunal assemblages were then reworked into glacial deposits (both glaciomarine and subglacial) during a late stage, or post, MIS3 ice advance of local glaciers to the Svartenhuk coast.

Further chronological control from all three valleys would undoubtedly improve our understanding of the 
glacial depositional history of the Svartenhuk coast, however, our existing understanding of the sediment/landforms at most of the sites studied suggests they share a similar glacial history that postdates MIS 3. In Arfertuarssuk there is evidence for two glacial advances separated by a period of deltaic deposition and constrained by shell ages ranging from $44097 \pm 1177$ to $39796 \pm 1137{ }^{14} \mathrm{C}$ yrs BP (SUERC43159 and SUERC-45905; Table 4; Fig. 12) This is partially mirrored at Kugssineq where the first advance is represented by glaciotectonic disturbance of the bedrock (LFA1) and at Tasiussaq where a later advance has overridden deltaic sediments at Sites 7 and 8 containing reworked plant remains dated to $42643 \pm 1632{ }^{14} \mathrm{C}$ yrs BP (SUERC-45900; Table 4). It should be noted, however, that additional chronological complexity is introduced to the glacial history of the area by Site 9 at the south-western end of Tasiussaq, where samples SUERC-45901 and SUERC45902 both returned Early Holocene ages (Table 4; Figs. 4 and 13). As Site 9 is a glacially over-ridden delta/fan complex, the sediments within it must support a late phase Early Holocene glacial re-advance over the site. Such a late advance could be further corroborated by the emplacement of eskers over Sites 7 and 8 just up-ice in the valley (LFA5b; Figs. 8a and 12). Critically, therefore, the sedimentological findings and range of dates within the glacial landforms from MIS 3 through to the Early Holocene illustrate that outlet glaciers from the interior of Svartenhuk advanced and retreated to the coast several times post MIS 3.

Further constraint upon age of deposition of these sediment and landforms along the Svartenhuk coast can be provided by the relative height of deposits and their relationship to former sea-level, although no local relative sealevel curve exists for the Svartenhuk Halvø or Uummannaq region at present. Despite this, the local marine limit from this study (75 $\mathrm{m}$ a.s.l.) is in broad agreement with both isolation basin studies in central Disko Bugt [59] and modelling results from the Uummannaq region [57] which place the Holocene marine limit in these areas at $\sim 70 \mathrm{~m}$ a.s.l. This suggests both areas have experienced a similar magnitude of glacioisostatic uplift and may share a similar post LGM relative sea-level history, but the (a)synchroneity and timing of this potential Holocene uplift and sea-level record remains unexplored.

\section{Implications for regional ice sheet history}

Through remote mapping and extensive ground-truthing, both geomorphological and sedimentological data provide compelling evidence for glacier expansion to the present coastline and its subsequent retreat to the Svartenhuk Halvø interior. This is in clear contrast to previous studies which have only reported evidence for restricted valley glaciation, leaving little-to-no imprint on the landscape. Based upon geomorphological mapping, ice flow indicators and clast lithological composition, glaciation of the peninsula was characterised by large valley glaciers which were sourced from high-elevation ice caps. The geomorphological signal of glaciation across many parts of Svartenhuk is patchy and subtle. This is a result of local, cold-based ice caps over high ground partially protecting the pre-glacial landscape However, these cold-based source areas fed warm-based outlet glacier systems to the coast leading to the formation of both advance and retreat phase erosional and depositional glacial landforms.

Very little evidence exists for the presence of any widespread ice sheet or ice stream activity within any of the valleys studied. If the peninsula was affected by the UIS, extensive erratic boulders would be common close to the low elevation present coastline of southern Svartenhuk where the ice stream moved onshore. There is no evidence for this, either during or following the deposition of the sediments throughout southern Svartenhuk Halvø. We therefore propose that the build-up of an independent coldbased ice cap over Svartenhuk during the onset of full glacial conditions would have protected the peninsula from inundation by both main ice sheet and the UIS as it moved from east to west into Baffin Bay. Furthermore, the buildup of an independent ice cap and valley glacier expansion on Svartenhuk may have been a fundamental trigger for the onset of the UIS during glacial cycles as a consequence of the re-routing of outlet glaciers to east of Svartenhuk (fed from the GrIS) in a southwards trajectory into the Igdlorssuit Sund and Uummannaq trough systems. Thus, our tentative correlation of deposits on Svartenhuk to MIS $2 / 3$ and the build-up of an independent ice mass on Svartenhuk would support the early switching on of the UIS during the last glacial cycle $[69,80]$. Such a pattern of regional ice build-up could theoretically be repeated during multiple previous glacial cycles and therefore potentially provide a strong positive feedback on glacial landscape evolution in this part of West Greenland.

\section{Conclusions}

Morphosedimentary investigation of deposits from three valleys in southern Svartenhuk Halvø has produced compelling evidence for the expansion of warm-based glaciers to the present coastline post MIS 3. These findings contrast somewhat with results from previous research in the Svartenhuk Halvø region which interpreted the sediments as littoral marine sediments deposited during MIS 5. Our geomorphic and sedimentological analysis demonstrates the widespread occurrence of moraines; overridden, striated and glaciotectonised bedrock and subglacial till 
deposition; esker formation; ice-contact deltas; and pitted outwash systems formed as a result of glacial activity. Although some evidence was found to support the occurrence of glacial marine sediments with mixed, interglacial/ glacial macro- and microscale faunal assemblages, such sediments show evidence for subglacial reworking on two separate occasions in the coastal lowlands of Svartenhuk. New 14C dates from the area suggest outlet glaciers from the interior of Svartenhuk advanced and retreated to the coast several times post MIS 3 and possibly as late as the Early Holocene. Svartenhuk Halvø was not overrun by the main Greenland ice sheet during the last glacial cycle, but the early development of an independent ice cap across this region as early as MIS 3 may have been instrumental in determining the dynamic evolution of the Uummannaq ice stream onset zone during the last glacial cycle and beyond.

Acknowledgments This work was supported by the Department of Geography (Durham University), the RGS-IBG and a NERC Radiocarbon Facility NRCF010001 (allocation numbers 1559.0411 and 1627.0312). Thanks to Arne Neumann, Birte Ørum, Barbara StroemBaris and Harrhy James for logistical support and to NERC Radiocarbon Facility staff for the preparation of radiocarbon samples. The reviewers are thanked for their comments which helped to improve the manuscript.

\section{References}

1. Andrews JT, Shimizu K (1966) Three-dimensional vector technique for analyzing till fabrics: discussion and FORTRAN program Geological. Bulletin 8:151-165

2. Ballantyne CK (1982) Aggregate clast form characteristics of deposits near the margins of four glaciers in the Jotunheimen Massif, Norway. pp 103-113

3. Bannerjee I, McDonald BC (1975) Nature of esker sedimentation. In: Jopling AV, McDonald BC (eds) Glaciofluvial and glaciolacustrine sedimentation, vol 23. SEPM Special Publications, Tulsa, pp 132-154

4. Bates CC (1953) Rational theory of delta formation. Am Assoc Pet Geol Bull 37:2119-2161

5. Benn D, Evans DJA (2010) Glaciers and glaciation, 2nd edn. Hodder Education, London

6. Benn DI (1994) Fabric shape and the interpretation of sedimentary fabric data. J Sediment Res Sect A Sediment Petrol Process 64A:910-915

7. Benn DI (1995) Fabric signature of till deformation, Breiðamerkurjökull, Iceland. Sedimentology 42:735-747

8. Benn DI, Ballantyne CK (1994) Reconstructing the transport history of glacigenic sediments: a new approach based on the covariance of clast form indices. Sediment Geol 91:215-227. doi:10.1016/0037-0738(94)90130-9

9. Benn DI, Evans DJA (1993) Glaciomarine deltaic deposition and ice-marginal tectonics: the 'Loch Don Sand Moraine', Isle of Mull, Scotland. J Quat Sci 8:279-291. doi:10.1002/jqs. 3390080402

10. Benn DI, Evans DJA (1996) The interpretation and classification of subglacially-deformed materials. Quat Sci Rev 15:23-52. doi:10.1016/0277-3791(95)00082-8
11. Bennett MR, Waller RI, Glasser NF, Hambrey MJ, Huddart D (1999) Glacigenic clast fabric: Genetic fingerprint or wishful thinking? J Quat Sci 14:11

12. Bennike O (2000) Palaeoecological studies of Holocene lake sediments from west Greenland. Palaeogeogr Palaeoclimatol Palaeoecol 155(3):285-304

13. Bennike O, Hansen KB, Knudsen KL, Penney DN, Rasmussen KL (1994) Quaternary marine stratigraphy and geochronology in central west Greenland. Boreas 23:194-215

14. Bertran P, HÉTu B, Texier J-P, Van Steijn H (1997) Fabric characteristics of subaerial slope deposits. Sedimentology 44:1-16. doi:10.1111/j.1365-3091.1997.tb00421.x

15. Bertran P, Texier J-P (1999) Facies and microfacies of slope deposits. CATENA 35:99-121. doi:10.1016/S0341-8162(98)00096-4

16. Boulton G, Eyles N (1979) Sedimentation by valley glaciers: a model and genetic classification. Moraines Varves 33:11-23

17. Boulton GS, Jones AS (1979) Stability of temperate ice caps and ice sheets resting on beds of deformable sediment. J Glaciol 24:29-43

18. Bull W (1977) The alluvial fan environment. Prog Phys Geogr $1: 49$

19. Cheel RJ, Rust BR (1982) Coarse grained facies of glaciomarine deposits near Ottawa, Canada. In: Davidson-Arnott R, Nickling W, Fahey BD (eds) Research in glaciofluvial and glaciolacustrine systems. Geobooks, Norwich

20. Clemmensen LB, Houmark-Nielsen M (1981) Sedimentary features of a Weichselian glaciolacustrine delta. Boreas 10:229-245. doi:10.1111/j.1502-3885.1981.tb00484.x

21. Croot DG, Sims PC (1996) Early stages of till genesis: an example from Fanore, County Clare, Ireland. Boreas 25:37-46

22. Dahl-Jensen D et al (2013) Eemian interglacial reconstructed from a Greenland folded ice core. Nature 493:489-494

23. DeWolf Y (1988) Stratified slope deposits. In: Clark MJ (ed) Advances in periglacial geomorphology. Wiley, Chichester, pp 91-110

24. Domack EW, Lawson DE (1985) Pebble fabric in an ice-rafted diamicton. J Geol 93:577-591

25. Dowdeswell J, Hogan K, Ó Cofaigh C, Fugelli E, Evans J, Noormets R (2014) Late Quaternary ice flow in a West Greenland fjord and cross-shelf trough system: submarine landforms from Rink Isbrae to Uummannaq shelf and slope. Quat Sci Rev 92:292-309

26. Dowdeswell JA, Sharp MJ (1986) Characterization of pebble fabrics in modern terrestrial glacigenic sediments. Sedimentology 33:699-710. doi:10.1111/j.1365-3091.1986.tb01970.x

27. Edwards MB (1986) Glacial environments. In: Reading HG (ed) Sedimentary environments and facies. Blackwell, Oxford, pp 416-438

28. Evans DJA, Benn DI (2004) A practical guide to the study of glacial sediments. Arnold, London

29. Evans DJA, Hiemstra JF (2005) Till deposition by glacier submarginal, incremental thickening. Earth Surf Proc Land 30:1633-1662. doi:10.1002/esp.1224

30. Evans DJA, Phillips ER, Hiemstra JF, Auton CA (2006) Subglacial till: formation, sedimentary characteristics and classification. Earth Sci Rev 78:115-176. doi:10.1016/j.earscirev.2006. 04.001

31. Francou B (1990) Stratification mechanisms in slope deposits in high subequatorial mountains. Permafr Periglac Process 1:249-263. doi:10.1002/ppp.3430010305

32. Funder S (1989) The Baffin-Bay region during the last interglaciation-evidence from northwest Greenland. Geographie Physique Et Quaternaire 43(3):255-262

33. Funder S, Hjort C, Kelly M (1991) Isotope stage 5 (130-74 ka) in Greenland, a review. Quat Int 10-12:107-122. doi:10.1016/10406182(91)90044-o 
34. Funder S, Hjort C, Landvik JY (1994) The last glacial cycles in east Greenland, an overview. Boreas 23:283-293

35. Funder S, Kjeldsen KK, Kjær KH, Ó Cofaigh C (2011) The Greenland ice sheet during the past 300,000 years: a review. In: Ehlers J, Gibbard PL, Hughes PD (eds) Quaternary glaciationsextent and chronology: a closer look. Elsevier, Oxford, pp 699-713

36. Fyfe GF (1990) The effect of water depth on ice-proximal glaciolacustrine sedimentation: salpausselka I, southern Finland. Boreas 19:18

37. Gelting P (1934) Studies on the vascular plants of East Greenland between Franz Joseph Fjord and Dove Bay. Meddelelser om Gronland 101

38. Gilbert GK (1885) The topographic features of lake shores US Geological Survey. Annu Rep 5:49

39. Goldthwait RP, Matsch CL (1989) Genetic classification of glacigenic deposits

40. Goossens D (2008) Techniques to measure grain-size distributions of loamy sediments: a comparative study of ten instruments for wet analysis. Sedimentology 55:65-96

41. Gustavson TC, Boothroyd JC (1987) A depositional model for outwash, sediment sources, and hydrologic characteristics, Malaspina Glacier, Alaska: A modern analog of the southeastern margin of the Laurentide ice sheet. Geol Soc Am Bull 99:187-200

42. Harris C (1991) Glacial deposits at Wylfa Head, Anglesey, North Wales: Evidence for Late Devensian deposition in a non-marine environment. J Quat Sci 6:67-77. doi:10.1002/jqs.3390060108

43. Hart JK (1994) Till fabric associated with deformable beds. Earth Surf Proc Land 19:15-32

44. Hart JK, Roberts DH (1994) Criteria to distinguish between subglacial glaciotectonic and glaciomarine sedimentation, I. Deformation styles and sedimentology. Sediment Geol 91:191-213

45. Henderson G, Pulvertaft TCR (1987a) Descriptive text to geological map of Greenland 1:100,000, Marmorilik 71 V.2 Agnete Syd, Nugatsiaq 71 V.2 Nord and Pangnertôq 72 V.2 Syd. Geol. Survey Greenland, Copenhagen

46. Henderson G, Pulvertaft TCR (1987b) Geological map of Greenland, 1:100 000, Mârmorilik 71 V.2 Syd, Nûgâtsiaq 71 V.2 Nord, Pangnertôq 72 V.2 Syd. Copenhagen

47. Henderson G, Pulvertaft TCR (1987c) Geological map of Greenland, 1:100 000, Mârmorilik 71 V.2 Syd, Nûgâtsiaq 71 V.2 Nord, Pangnertôq 72 V.2 Syd. Descriptive text. Geological Survey of Greenland., Copenhagen

48. Hicock SR (1992) Lobal interactions and rheologic superposition in subglacial till near Bradtville, Ontario, Canada. Boreas 21:73-88

49. Hicock SR, Fuller EA (1995) Lobal interactions, rheologic superposition, and implications for a Pleistocene ice stream on the continental shelf of British Columbia. Geomorphology 14(2):167-184

50. Hiemstra JF, Evans DJA, Cofaigh CO (2007) The role of glacitectonic rafting and comminution in the production of subglacial tills: examples from southwest Ireland and Antarctica. Boreas 36:386-399

51. Kelly M (1986) Quaternary, pre-holocene, marine events of western Greenland. Grønlands geologiske Undersøgelse 131:23

52. Kenyon PM, Turcotte DL (1985) Morphology of a delta prograding by bulk sediment transport. Geol Soc Am Bull 96:1457-1465. doi:10.1130/0016-7606(1985)96<1457:moadpb>2.0.co;2

53. Kleman J, Glasser NF (2007) The subglacial thermal organisation (STO) of ice sheets. Quat Sci Rev 26:585-597

54. Lane TP, Roberts DH, Ó Cofaigh C, Vieli A, Rea B (2015) Glacial landscape evolution in the Uummannaq region, West Greenland Boreas
55. Lane TP, Roberts DH, Rea BR, Ó Cofaigh C, Vieli A, Rodés A (2014) Controls upon the last glacial maximum deglaciation of the northern Uummannaq ice stream system, West Greenland. Quat Sci Rev 92:324-344

56. Laursen D (1944) Contributions to the quaternary geology of northern West Greenland especially the raised marine deposits. Meddelelser om Gronland 135:125

57. Lecavalier BS et al (2014) A model of Greenland ice sheet deglaciation constrained by observations of relative sea level and ice extent. Quat Sci Rev 102:54-84

58. Lindsay JF (1970) Clast fabric of till and its development. J Sediment Res (SEPM) 40:629-641

59. Long AJ, Roberts DH, Wright MR (1999) Isolation basin stratigraphy and Holocene relative sea-level change on Arveprinsen Ejland, Disko Bugt, West Greenland. J Quat Sci 14:323-345

60. Lønne I (1993) Physical signatures of ice advance in a Younger Dryas ice-contact delta, Tromso, northern Norway: implications for glacier-terminus history. Boreas 22:12

61. Lønne I (1995) Sedimentary facies and depositional architecture of ice-contact glaciomarine systems. Sediment Geol 98:13-43. doi:10.1016/0037-0738(95)00025-4

62. Lønne I, Nemec W (2004) High-arctic fan delta recording deglaciation and environment disequilibrium. Sedimentology 51:553-589

63. Lukas S, Benn D, Boston CM, Brook, M, Coray S, Evans DJA, Graf A, Kellerer-Pirklbauer A, Kirkbride MP, Krabbendam M, Lovell H, Machiedo M, Mills SC, Nye K, Reinardy BTI, Ross FH, Signer M (2013) Clast shape analysis and clast transport paths in glacial environments: a critical review of methods and the role of lithology. Earth Sci Rev 121:96-116

64. Maizels J (1992) Boulder ring structures produced during Jökulhlaup flows. origin and hydraulic significance. Geografiska Annaler Ser A Phys Geogr 74:21-33

65. Maizels JK (1977) Experiments on the origin of kettle-holes. J Glaciol 18:291-303

66. Murton JB (1996) Near-surface brecciation of chalk, isle of thanet, south-east England: a comparison with ice-rich brecciated bedrocks in Canada and Spitsbergen. Permafr Periglac Process 7:153-164. doi:10.1002/(sici)1099-1530(199604)7:2<153:aidppp215>3.0.co;2-7

67. Nemec W, Steel RJ (1984) Alluvial and coastal conglomerates: their significant features and some comments on gravelly massflow deposits. In: Koster EH, Steel RJ (eds) Sedimentology of gravels and conglomerates. Canadian Society of Petroleum Geologists, Canada, pp 1-31

68. Ó Cofaigh C, Andrews JT, Jennings AE, Dowdeswell JA, Hogan KA, Kilfeather AA, Sheldon C (2013) Glacimarine lithofacies, provenance, and depositional processes on a West Greenland trough-mouth fan. J Quat Sci 28:13-26

69. Ó Cofaigh $\mathrm{C}$ et al (2013) An extensive and dynamic ice sheet on the West Greenland shelf during the last glacial cycle. Geology 41:219-222. doi:10.1130/g33759.1

70. Ó Cofaigh C, Evans DJA, Hiemstra JF (2011) Formation of a stratified subglacial 'till' assemblage by ice-marginal thrusting and glacier overriding. Boreas 40:1-14. doi:10.1111/j.1502-3885. 2010.00177.x

71. Phillips E, Lee JR, Riding JB, Kendall R, Hughes L (2013) Periglacial disruption and subsequent glacitectonic deformation of bedrock: an example from Anglesey, North Wales, UK. Proc Geol Assoc 124:802-817

72. Postma G, Roep TB (1985) Resedimented conglomerates in the Bottomsets of Gilbert-type Gravel Deltas. J Sediment Res (SEPM) 55:12

73. Price RJ (1970) Moraines at Fjallsjökull, Iceland. Arct Alp Res 2:27-42 
74. Rea B, Evans DJA (2003) Plateau icefield landsystem. In: Evans DJA (ed) Glacial landsystems. Arnold, London

75. Reimer PJ et al (2013) IntCal13 and Marine13 radiocarbon age calibration curves $0-50,000$ years cal BP

76. Rich JL (1943) Buried stagnant ice as a normal product of a progressively retreating glacier in a hilly region. Am J Sci 241:95-100

77. Rink H (1853) Udsigt over Nordgronlands Geognosie Kongelige danske Videnskabernes. Selskabs Skrifter 5:23

78. Roberts DH, Long AJ, Davies BJ, Simpson MJR, Schnabel C (2010) Ice stream influence on West Greenland Ice Sheet dynamics during the Last Glacial Maximum. J Quat Sci 25:850-864

79. Roberts DH, Long AJ, Schnabel C, Davies BJ, Xu S, Simpson MJR, Huybrechts P (2009) Ice sheet extent and early deglacial history of the southwestern sector of the Greenland Ice Sheet. Quat Sci Rev 28:2760-2773

80. Roberts DH, Rea BR, Lane TP, Schnabel C, Rodes A (2013) New constraints on Greenland ice sheet dynamics during the last glacial cycle: evidence from the Uummannaq ice stream system. J Geophys Res Earth Surf 118:23

81. Sneed ED, Folk RL (1958) Pebbles in the lower Colorado River, Texas a study in particle morphogenesis. J Geol 66:114-150

82. Sperazza M, Moore JN, Hendrix MS (2004) High-resolution particle size analysis of naturally occurring very fine-grained sediment through laser diffractometry. J Sediment Res 74:736-743
83. Steenstrup KVJ (1883) Om Forekomsten af Forsteninger i de kulførende Dannelser i Nord-Grønland. Meddelelser om Grønland 5:43-67

84. Sugden DE (1974) Landscapes of glacial erosion in Greenland and their relationship to ice, topographic and bedrock conditions. In: Brown EH, Waters RS (eds) Progress in geomorphology: papers in honour of David L. Linton. Institute of British Geographers Special Publication. No. 7. Institute of British Geographers, London, pp 177-195

85. Swift DA, Persano C, Stuart FM, Gallagher K, Whitham A (2008) A reassessment of the role of ice sheet glaciation in the long-term evolution of the East Greenland fjord region. Geomorphology 97:109-125

86. van der Wateren FM (1995) Processes of glaciotectonism. In: Menzies J (ed) Modern glacial environments: processes, dynamics and sediments. Butterworth-Heinemann, Oxford, pp 309-335

87. van Steijn H (1996) Debris-flow magnitude-frequency relationships for mountainous regions of Central and Northwest Europe. Geomorphology 15:259-273

88. Van Steijn H, Boelhouwers J, Harris S, Hétu B (2002) Recent research on the nature, origin and climatic relations of blocky and stratified slope deposits. Prog Phys Geogr 26:551-575

89. Warren WP, Ashley GM (1994) Origins of the ice-contact stratified ridges (eskers) of Ireland. J Sediment Res 64:433-449

90. Whillans IM (1978) Erosion by continental ice sheets. J Geol 86:9 